\title{
第22回 日本肝蔵学会総会抄録（3）
}

\author{
期日：昭和61年 6 月 12,13 日 \\ 会場：山梨県立県民文化ホール \\ 会長：鈴木宏

\section{パネルディスカッション \\ B 型慢性肝炎の治療：病態からみた評価}

\author{
司会：瀧野 辰郎（京都府立医科大学第三内科） \\ 古田 精市（信州大学第二内科） \\ インターフェロン投与時における肝組織内のウイルス, \\ 抗ウイルス状態，免疫系の変動
}
小川 泰史 堀池 典生 太田 康幸
（愛媛大学医学部第三内科）

\section{目的}

自然経過の B 型慢性肝炎では, 肝機能の急性増悪 (シューブ)に伴い, HBe 抗原が消失することが多い1). そこで，自然経過例およびインターフェロン(IFN)投 与例において，末梢血および肝組織内 HBウイルス， 抗ウイルス状態，免度系の変動について検索・比較し， 各種病態の面から IFN 療法の有効性および問題点に ついて検討した。

\section{対象およひ方法}

対象は $\mathrm{HBe}$ 抗原陽性の B 型慢性肝炎43例である。 IFN 治療17例，特殊治療 (一) 26例. IFN は， $\alpha$ 型を $300-600$ 万単位/日, recombinant- $\alpha$ t600-1,800万 単位/日, $\beta$ 型300万単位/日, 総量 4,800 万 47,700 万単 位， 4 週 6 力月間投与し，投与後 $12 \sim 42$ 力月（平均 18力月) 観察した。 ウイルス学的検索は $\mathrm{HBe}$ 抗原・抗 体(RIA 法), 血中 HBV DNA-Polymerase (DNA-P) 活性は Kaplan変法, 肝組織 $\mathrm{HBc}$ 抗原は AvidinBiotin-Peroxidase complexを用いた醉素抗体間接 法, HBV DNA は in situ hybridization 法 $\left({ }^{3} \mathrm{H}\right)$ を 用いておこなった。抗ウイルス状態は，末梢血単核球 および肝組織内 $2^{\prime}, 5^{\prime}$-oligoadenylate synthetase (2-5 A synthetase）活性を測定した。免疫学的検索は，末 梢血リンパ球 T cell subsets (Flow cytometry 法), 肝組織内 OKT 4, 8, Leu 7 陽性細胞および肝細胞膜
HLA-class I (Avidin-Biotin Peroxidase complex 用いた醭素抗体間接法)についておこなった。

\section{成 樍}

(1) 自然経過例の検討

自然経過の B 型慢性肝炎のうち HBe 抗原の seroconversion（sC）を起こした 8 例中 8 例に肝機能の急 性増悪 (シューブ)をみとめた。 シューブに先立ち血 中 DNA-Pの上昇を26例中24例(92\%)にみとめた。末 梢血単核球2-5 A synthetase 活性は DNA-P の上昇時 に高く，以降減少し：シニーブ極期には低下した。末 梢血リンパ球 T cell subsetsは, シューブ時 OKT 4 の 増加をみとめ, OKT $4 / 8$ は有意に増加した。肝組織内 OKT 8 陽性細胞む $246 \pm 152 / \mathrm{mm}^{2}$ 子寛解期 $113 \pm 44 /$ $\mathrm{mm}^{2}$ に比べ有意に增加した。一方, Leu 7 陽性細胞は, 末梢血, 肝組織内ともに変化しなかった。

（2）IFN 治療例における検討

IFN 治療例17例について, IFN 前扰よび投与終了直 後における各種マーカーの変動を検索した.

IFN 治療例の sc 率は，6 6 力月後17例中 5 例(29\%), 1 年後16例中 4 例 (25\%) であった。

血中 DNA-P 活性は，IFN 投与中では16例中12例 (75\%)，投与終了直後では16例中 8 例 $(50 \%)$ 陰性化 した. 肝組織 $\mathrm{HBc}$ 抗原は，8例について検討したが， IFN 投与前陽性の 4 例全例とも陰性化した。盰組織 
Table 1 Changes of HBV DNA in serum and liver tissue following interferon treatment.

\begin{tabular}{|c|c|c|c|c|c|c|c|c|c|}
\hline \multirow{3}{*}{ Case } & \multicolumn{3}{|c|}{ Interferon } & \multirow{2}{*}{\multicolumn{2}{|c|}{$\begin{array}{c}\text { Serum } \\
\text { DNA-P (cpm) }\end{array}$}} & \multicolumn{4}{|c|}{ Liver tissue } \\
\hline & \multirow{2}{*}{ Type } & \multicolumn{2}{|c|}{ Dose $\left(\times 10^{8}\right)$} & & & \multicolumn{2}{|c|}{$\mathrm{HBcAg}$} & \multicolumn{2}{|c|}{ HBV-DNA } \\
\hline & & /Day & Total & b & a & b & $\mathbf{a}$ & $\mathbf{b}$ & $\mathbf{a}$ \\
\hline 1 & $\beta$ & 3 & 102 & 952 & 600 & & & & \\
\hline 2 & $\beta$ & 3 & 102 & 174 & 88 & & & & \\
\hline 3 & $\beta$ & 3 & 312 & 328 & 187 & & & & \\
\hline 4 & $\beta$ & 3 & 312 & 204 & 75 & & & & \\
\hline 5 & $\beta$ & 3 & 312 & 388 & 181 & + & - & & \\
\hline 6 & $\beta$ & 3 & 171 & 377 & 281 & + & - & + & - \\
\hline 7 & $\beta$ & 3 & 144 & 491 & $\mathrm{NE}$ & & & & \\
\hline 8 & $\beta$ & 3 & 135 & 4510 & 143 & + & - & & \\
\hline 9 & $\alpha$ & 3 & 48 & 263 & 146 & & & & \\
\hline 10 & $\alpha$ & 3 & 78 & 73 & 458 & & & & \\
\hline 11 & $\alpha$ & 6 & 252 & 450 & 270 & - & - & + & - \\
\hline 12 & $\alpha$ & 6 & 168 & 551 & 212 & - & - & + & - \\
\hline 13 & $r \cdot \alpha$ & 18 & 477 & 941 & 417 & & & & \\
\hline 14 & $r-\alpha$ & 18 & 477 & 327 & 92 & + & - & & \\
\hline 15 & $r-\alpha$ & 6 & 185 & 572 & 293 & - & - & + & - \\
\hline 16 & $r-\alpha$ & 6 & 185 & 536 & 250 & & & & \\
\hline 17 & $r-\alpha$ & 6 & 185 & 357 & 57 & - & - & + & - \\
\hline
\end{tabular}

b : before IFN treatment

a : after IFN treatment

HBV DNA 5 例全例とも消失した, HBV DNAの 消失した 5 例中 $\mathrm{HBe}$ 抗原の消失を 1 例，scを 2 例み とめた (Table 1)。末梢血単核球2-5 A synthetase 活 性は， $0.63 \pm 0.87 \%$ から最高 $3.8 \pm 3.9 \%(\mathrm{n}=11)$ と上 昇し, 肝組織内 $2-5$ A synthetase 活性も $3.9 \pm 4.3 \%$ 加

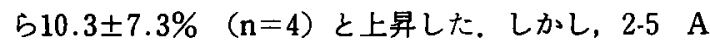
synthetase の上昇率と $\mathrm{HBe}$ 抗原に対する効果の間に は，明らかな相関はみられなかった (Table 2)。

肝細胞膜 HLA-class Iは， 7 例について検討した が，IFN 投与により 5 例で増強をみとめた。末梢血り ンバ球 T cell subsetsは，IFN 投与により著明な変動 を示さなかった。 また， $\mathrm{HBe}$ 抗原の陰性化， HBe 抗体 の出現例でも，特徽的な変動はみとめなかった（Fig. 1). 肝組織内 OKT 4, 8, Leu 7 陽性細胞は, IFN 投与 により著减し，とくにOKT 8 陽性細胞は225 $2176 /$ $\mathrm{mm}^{2}$ から $72 \pm 49 / \mathrm{mm}^{2} に$, Leu 7 陽性細胞は $17 \pm 10 /$

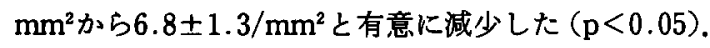

\section{考 察}

B 型慢性肝炎は, HBV 感染肝細胞に対する細胞性 免疫反応により生(゙2), HBV 感染肝細胞の消失によっ て鎮静化すると考えられている，したがって，著者ら は HBV の排除には，いかなる生体の機構が作動して
Table 2 Changes of 2-5 A synthetase activity in PBMC and liver tissue following interferon treatment.

\begin{tabular}{c|c|c|c|c|c}
\hline \multirow{2}{*}{$\begin{array}{c}\text { Type of } \\
\text { IFN }\end{array}$} & \multicolumn{2}{|c|}{$2-5$ synthetase activity (\%) } & \multirow{2}{*}{ HBeAg/Ab* } \\
\cline { 2 - 5 } & \multicolumn{2}{|c|}{ PBMC } & \multicolumn{2}{c|}{ liver tissue } & \multirow{2}{*}{ HBeAs } \\
\cline { 2 - 5 } & $\mathrm{b}$ & $\mathrm{d}$ & $\mathrm{b}$ & $\mathrm{d}$ & \\
\hline$\beta$ & 0.1 & 4.0 & & & \\
$\alpha$ & 0.47 & 13.1 & 8.9 & 16.9 & \\
$\beta$ & 0.70 & 18.5 & & & $-/+$ \\
$\beta$ & 0.21 & 1.3 & 0.01 & 1.3 & \\
$\alpha$ & 1.0 & 5.9 & & & \\
\hline $\mathrm{r}-\alpha$ & 0.12 & 3.5 & & & \\
$\mathrm{r}-\alpha$ & 0.18 & 1.1 & & & $-/-$ \\
\hline$\alpha$ & 0.22 & 8.5 & 6.1 & 15.6 & \\
$\mathrm{r}-\alpha$ & 0.26 & 2.9 & & & \\
$\alpha$ & 0.34 & 2.2 & & & $+/-$ \\
$\mathrm{r}-\alpha$ & 0.47 & 2.9 & 0.65 & 7.5 & \\
$\alpha$ & 3.1 & 13.1 & & & \\
\hline
\end{tabular}

PBMC : peripheral blood mononuclear cells b : before interferon treatment d : during interferon treatment (maximal levels)

$\because 1$ year after interferon treatment 


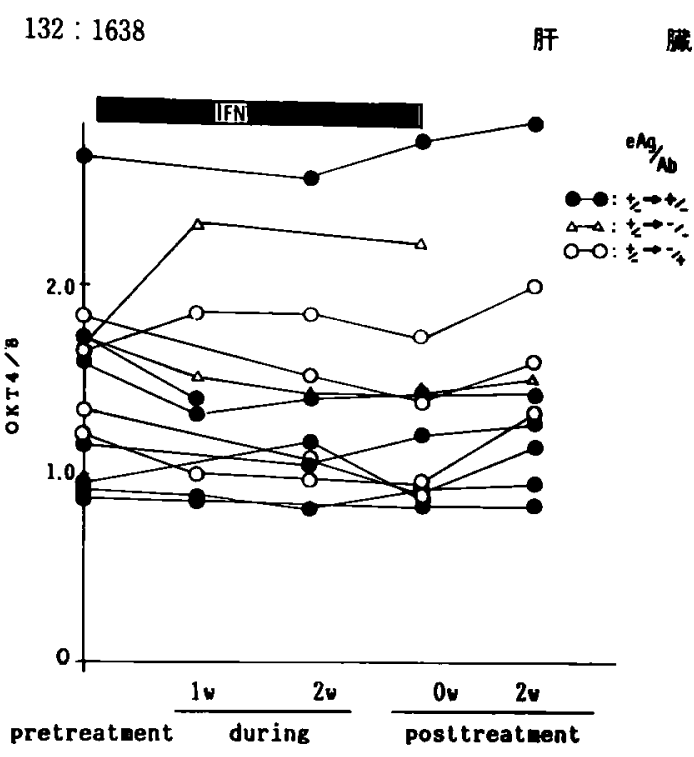

Fig. 1 Change of $\mathrm{T}$ cell subsets (OKT4/8) following interferon treatment.

いるかを自然経過例の肝機能増悪時において検討し た. 肝機能の増悪時には, それに先立ち HBV の増殖, 2-5 A synthetase 活性の上昇，極期には末梢血リンハ 球OKT 4の上昇扣よび肝組織内 OKT 8 陽性細胞の増 加を認めた。したがって, HBV の排除には, Schattner ら゙の報告にみられるよらに, interferon systemを主 とした抗ウイルス作用とともに， cytotoxic T cellsに よる HBV 感染肝細胞破壊の機構が働いていると思わ れる。一方，IFN 療法では，末梢血単核球および肝組 織2-5 A synthetase 活性, 肝細胞膜 HLA-class I の増 強を認め，肝組織内 HBV の減少を証明しえたか，末梢 血リンパ球 $\mathrm{T}$ cell subsetsの变動は弱く, 肝組織内
OKT 8 陽性細胞の减少を認め, Dooly ら"が報告した 上5に，免废学的增強は認めなかった. Yokosuka ら5) は，IFN 治療により HBV 複製の鋳型となる supercoiled form が残存すると報告しているが，著者らが報 告した細胞性免疫能增強の弱さと考古合わせると，今 後の IFN 療法は，免疫賦活剤との併用による HBV 感 染肝細胞破壊により，上り有効なるのになると思われ る.

索引用語：インターフェロン (IFN), HBV DNA, $2^{\prime}, 5^{\prime}$-oligoadenylate synthetase (2-5 A synthetase)

\section{文献}

1) Liaw YF, Chu CM, Huang MJ, et al: Determinants for hepatitis $B$ e antigen clearance in chronic type B hepatitis. Liver $4: 301-306,1984$

2) Vento $S$, Hegary JE, Alberti $A$, et al: $T$ lymphocyte sensitization to $\mathrm{HBcAg}$ and $\mathrm{T}$ cellmediated unresponsiveness to $\mathrm{HBsAg}$ in he. patitis $B$ virus-related chronic liver disease. Hepatology 5(2): 192-197, 1985

3) Schattner A, Wallach D, Merlin G, et al: Assay of an interferoninduced enzyme in white blood cells as a diagnostic aid in viral disease. Lancet i : 497-499, 1981

4) Dooley JS, Davis GL, Peters M, et al: Pilot study of recombinant human $\alpha$-interferon for chronic type B hepatitis. Gastroenterology 90 (1) : $150-157,1986$

5) Yokosuka $O$, Omata $M$, Imazeki $F$, et al: Changes of hepatitis $B$ virus DNA in liver and serum caused by recombinant leukocyte interferon treatment: analysis of intrahepatic replicative hepatitis B virus DNA. Hepatology 5 (5) : $728-734,1985$

\title{
B 型慢性肝炎に対するインターフェロン療法 一HBV 関連マーカーから見た治療効果の検討一
}

\author{
奥野 忠雄 阿部 芳道瀧野 辰郎 \\ （京都府立医科大学第三内科）
}

はじめに

B 型慢性肝炎に対するインターフェロン(IFN)投与 中の Hepatitis B Virus (HBV) マーカーの推移につ いての検討は多い，しかし，IFN 投与後の長期経過観 察例の検討は乏しい，著者らは IFN 単独療法後1.5年
から3.5年間経過観察し得た B 型慢性肝资の長期予後 を主として HBV マーカーの面より検討し若干の知見 を得たので報告する。

対象と方法

教室で過去 5 年間に肝生検にて B 型慢性肝次と診 


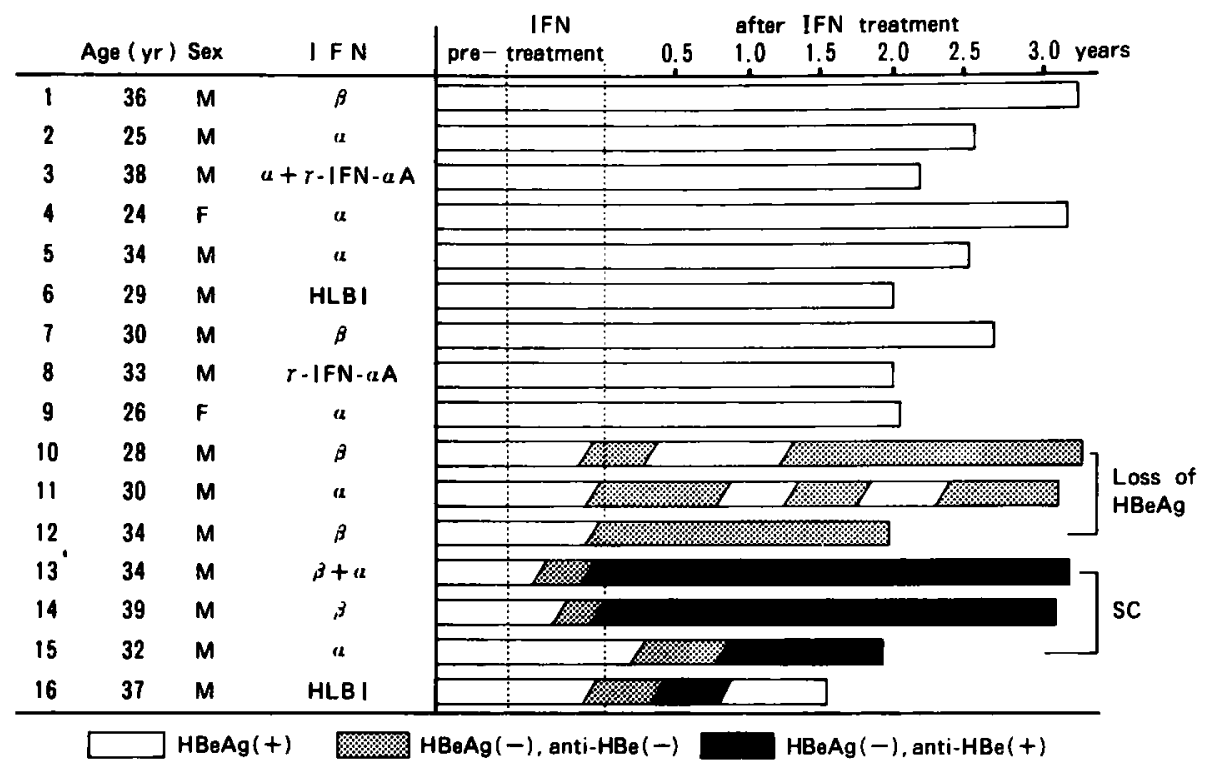

Fig. 1 Sequential changes of $\mathrm{HBeAg} / \mathrm{anti}-\mathrm{HBe}$ in chronic hepatitis $\mathrm{B}$ after the interferon treatment.

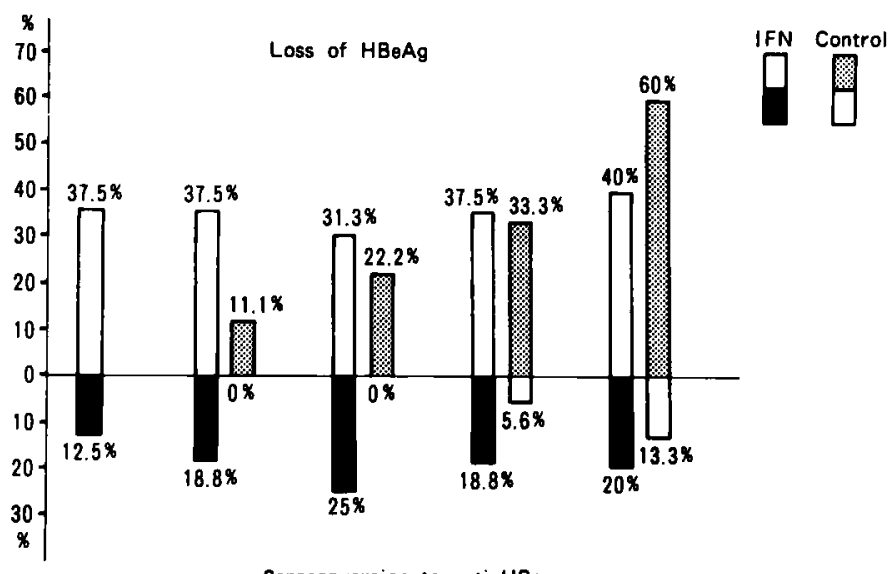

Seroconversion to anti-HBe

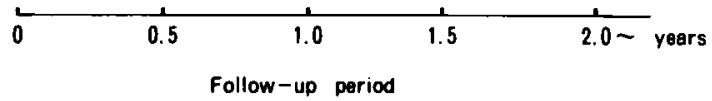

Fig. 2 Outcome of $\mathrm{HBeAg} / \mathrm{anti} \cdot \mathrm{HBe}$ in chronic hepatitis $\mathrm{B}$ with interferon treatment and without antiviral treatment.

断され，IFN 単独療法を行ったもののらち，投与終了 後1.5年から3.5年間経過観察し得た16症例 (IFN 群) を対象に HBV マーカーから見た長期予後を検討し た. 対照として同期間内に組織学的に B 型慢性肝炎と 診断され，抗ウイルス郕投与などの特殊療法を行わず，
初診時より1.5年以上経過観察可能であった18症例を コントロール群 (コ群) とした。両群の詳細はTable lのごとくであるが, コ群でIFN 群に比し，DNA polymerase (DNAP) および HBV DNA が有意に低 かった. DNAPはKaplan らリの方法により測定し40 
Table 1 Pretreatment characteristics of chronic hepatitis B with interferon treatment and without antiviral treatment.

\begin{tabular}{|c|c|c|}
\hline Characteristics & $\begin{array}{r}\text { Interferon } \\
(n=16)\end{array}$ & $\begin{array}{l}\text { Control } \\
(n=18)\end{array}$ \\
\hline Age $(y r)$ & $31.8 \pm 4.6^{a}$ & $38.3 \pm 9.6^{\mathrm{a}}$ \\
\hline Sex $(M: F)$ & $14: 2$ & $11: 7$ \\
\hline \multicolumn{3}{|l|}{ Liver Histopathology } \\
\hline $\mathrm{CAH}$ & 15 & 17 \\
\hline $\mathrm{CIH}$ & 1 & 1 \\
\hline SGPT (KU) & $120 \pm 98^{\circ}$ & $93 \pm 94^{a}$ \\
\hline $\mathrm{HB}_{\theta A g}(\mathrm{RIA})$ & positive & positive \\
\hline DNA polymerese (cpm) & $749 \pm 1406^{\circ}$ & $151 \pm 202^{8}$ \\
\hline HBV DNA (pg/ml serum) b & $1920 \pm 1623^{\circ}$ & $152 \pm 335^{a}$ \\
\hline $\begin{array}{l}\text { a } M e a n \pm S D, C A H=\text { chr } \\
C I H=\text { chronic inactive } \\
\text { b measured by dot hybri } \\
80 \mathrm{pg} / \mathrm{ml} \text { serum } \leqq \text { posi }\end{array}$ & $\begin{array}{l}\text { ic active hepati } \\
\text { lepatitis } \\
\text { eation method ; } \\
\text { en }\end{array}$ & \\
\hline
\end{tabular}

cpm 以上を陽性とした，HBV DNA の湘定は nick translation 法2)により ${ }^{3} \mathrm{H}-\mathrm{dTTP}$ で標識した組み換え HBV DNA をブローブとして dot hybridization 法に より行った. 使用した IFN の総投与量は0.95 4.77× $10^{8} \mathrm{IU}$ であった。投与期間は28日〜 52日間であり，2 例 で種類の異なった IFN が 2 回投与された。

\section{結 果}

IFN 投与後の $\mathrm{HBe}$ 抗原・抗体系の推移は Fig. 1 に 示すごとく，IFN 群ではIFN 投与中ないしは投与後 0.5年以内に HBe 抗原の陰性化がみられるのに比し, コ群では観察開始後 1 1.5年以降にみられた。また， seroconversion (SC) 率に関しては IFN 群で投与終了 後1.5年までコ群に比し有意に高い率であった（Fig. 2).DNAP の消失率はIFN 群では投与終了時および

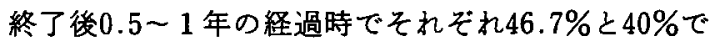
あるが，経過観察期間が長くなるにつれて低くなる傾 向がみられた，HBV DNA は IFN 群で投与終了時 3 例 (18.8\%) で消失し，0.5 1 年後には 2 例 (12.5\%) であったが， $\mathrm{HBe}$ 抗原陰性化群においても HBV DNA が 1 年以上持続して陰性化を示したものはな かった. SGPT の推移に関してはIFN 群で HBe 抗原 陰性化群と持続陽性群に分けて比較検討すると，陰性 化群で IFN 投与前の SGPT が高く，150KU 以上の変 動を示す例が多かった。 また SC 後 $\mathrm{HBe}$ 抗体が高值持 続するむののらち，2 例に SGPT の異常がみられた。 これらの例では SC 後す組織学的に改善が認められな かった。一方, HBe 抗原持続陽性群では SGPT の軽度 異常が持続した。

\section{考察}

Schalm ら゙は, IFN の HBV 関連マーカーに及ぼす 奻果は自然経過によると結論したが，今回，我々の成 縝では IFN 投与後 1 - 1.5年までの間は，コ群と比較 してIFN 群で HBe 抗原陰性化率および HBe 抗体へ の SC 率は有意に高かった。しかし，IFN 投与終了後 2 年以降はコ群との差が小さくなり，むしろコ群の 方が高くなることより自然経過によるものと考えられ た。 また， SC 後 $\mathrm{HBe}$ 抗体の高值持続陽性にもかかわ らず，SGPT の異常及び血清中 DNAP おょび HBV DNA が陽性を示す症例が 2 例みられた。当教室にて 過去 5 年間に組織学的に B 型慢性肝炎之診断され, $\mathrm{HBe}$ 杭体が高值持続陽性を示す 30 症例のうち, SGPT が100KU 以上の上昇を示し血清中 DNAP 及び HBV DNA が陽性であるものは 7 例 (23.3\%)であった。 こ の成績は Davis 54の報告した $32 \%$ に比べ，やや低率 であったか，ほほ20３0\%にこうした症例が認められ るものと考えられる。これらの例ではまた組織学的に む改善を認めず，活動性の病変を示すことが多い5)。こ のことは，HBVの reactivation が原因と考えられて おり，今後はこらした症例に対してもIFNなどの抗ウ イルス剤の投与を検討する必要があると思われた。

\section{結 語}

1) $\mathrm{HBe}$ 抗原・抗体系に及ぼす IFN 治療の効果判定 には，投与終了後 1 - 1.5年の経過観察で十分であると 考えられた。

2）IFN 治療が有効な例では SGPT が150KU 以上 の変動を示す慢性肝炎活動性であった。

3） $\mathrm{HBe}$ 抗体一 SC L，抗体価が高值持続陽性の 2 例で, HBV の增殂と関連してSGPT の異常が認めら れた。 これらの例ではSC 後も肝組織所見の改善が認 められなかった。

4) $\mathrm{HBe}$ 杭体が高値持続陽性の B 型慢性肝炎 30 例 中 7 例 (23.3\%) で HBV の増殖と関連して SGPT の 上昇が認められた。

象引用語：B 型慢性肝炎, インターフェロン, HBV マーカー

\section{文献}

1) Kaplan PM, Greenman RL, Gerin RL, et al: DNA polymerase associated with human hepatitis B antigen. J Virol 12 : 995-1005, 1973

2) Rigby PWJ, Dieckman $M$, Roodes $C$, et al: Labelling deoxyribonucleic acid to high specific activity in vivo by nick translation with DNA polymerase I. J Mol Biol 113 : 237-251, 1977 
3) Schalm SW, Heijitink RA: Spontaneous disappearance of viral replication and liver cell inflammation in HBsAg-positive chronic active hepatitis: results of a placebo vs. interferon trial. Hepatology 2 : 791-794, 1982

4) Davis GL, Hoofnagle JH, Waggoner JG: Spontaneous reactivation of chronic hepatitis $B$ virus infection. Gastroenterology $86: 230-235$, 1984

5) Fattovich G, Rugge $M$, Brollo $L$, et al : Clinical, virologic and histologic outcome following seroconversion from $\mathrm{HBeAg}$ to antiHBe in chronic hepatitis type B. Hepatology 6 : 167-172, 1986

\section{B 型慢性肝资の免疫療法における免疫学的動癿について

\author{
加登 康洋 極上 義伸 森本日出雄 \\ 田中 延善 小林 健一 \\ (金沢大学第一内科)
}

はじめに

B 型肝炎ウイルスの肝細胞破壊機序については，現 在のところ種々の面より検討されている. 現在のとこ

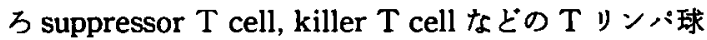
が， B 型肝炎ウイルスの肝細胞破壊機序と密接に関連 しているのではないかと考えられている。一方 B 型肝 炎の治療にインターフェロン, Ara-A などの抗ウイル ス療法，ステロイドホルモン, Transfer factor(T.F.) などの免疫療法が施行されているが，B型慢性活動性 肝炎において，免疫療法に上り，Tリン八球を主体と した免疫反応がどのような動態を呈するかについて不 明の点が多い，今回われわれは，B 型慢性活動性肝炎 において，e抗原が消失したり，e 抗体に seroconver- sionする場合には，どのような免疫反応を呈するかに ついて, e 抗原から e 抗体に seroconversion した症例 の肝組織中の $\mathrm{T}$ cell subsets, ステロイドホルモン， T.F. 投与などの免疫療法を施行した症例の投与前後 における末梢血 $\mathrm{T}$ cell subsetsについて検討をおこ なった.

\section{対象ならびに方法}

金沢大学第一内科にて診断した e 抗原から e 抗体に seroconversion した慢性活動性肝资 9 例，ステロイド ホルモンおよびAra A 併用群, ステロイドホルモン単 独群，T.F.などの投与をおこなった e 抗原陽性慢性活 動性肝炎33症例を対象とした。肝組織内 $\mathrm{T}$ cell subsets は, 抗ヒトリンバ球抗体として, Leu 4, Leu 3a, Leu
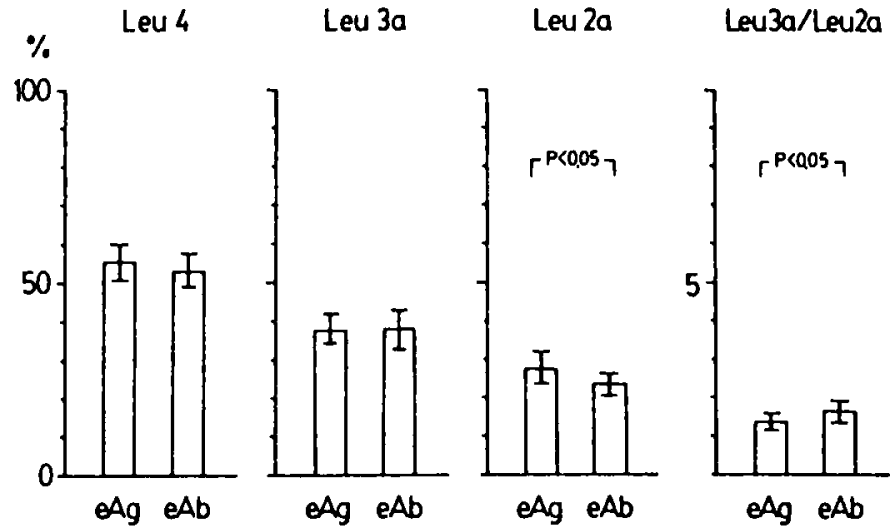

雨 mean:SD

$$
\text { eAg(t): } n=9
$$

$e A b(t): n=9$

Fig. 1 e 抗原, e 抗体時の肝組織内 $\mathrm{T}$ cell subsets. 
2aを用い, 䤃素抗体法にて, 肝組織内門脈域に浸潤す るリンパ球の subsets を，末梢血の $\mathrm{T}$ cell subsets は 抗リンバ球抗体として, OKT 3, OKT 4, OKT 8 を使 用して Flowcytometryにて検討した。 OKT 3, Leu 4 は pan T cell, OKT 4, Leu 3a は helper/inducer T cell, OKT 8, Leu 2a は suppressor/killer T cell とさ れている.

\section{成 䋶}

1）肝組織内 $T$ cell subsets の検討：門脈域全域に おける浸潤リンハ球の T cell subsetsを検討すると， Leu 4, Leu 3a 陽性細胞は, e 抗原陽性例, e 抗体陽性 例と両群間に差はみとめられなかった。しかし，Leu $2 \mathrm{a}$ 陽性細胞は $\mathrm{e}$ 抗原陽性例では $27.4 \pm 3.6 \%, \mathrm{e}$ 抗体 陽性例では $24.0 \pm 1.7 \%$ であり, e 抗体陽性例では, e 抗 原陽性例に比し少なく，その差は有意であった（ $\mathrm{p}<$ 0.05, Fig. 1). また Leu 3a/Leu 2a 比を検討すると， $\mathrm{e}$ 抗原陽性例では, $1.39 \pm 0.17, \mathrm{e}$ 抗体陽性例では1.6士 0.23 であり, e 抗体陽性例では, e 抗原陽性例に比し高 值を示し，その差は有意であった $(\mathrm{p}<0.05$, Fig. 1). 一方門脈域に括ける浸潤リンパ球の分布を検討するた めに, piecemeal necrosis部に拈ける各種モノクロー ナル抗体陽性を比較検討すると, e 抗体陽性例では $\mathrm{e}$ 抗原陽性例に比し, Leu 2a 陽性細胞は少ない傾向がみ られた。

2) e 抗原陽性慢性活動性肝炎における各種免疫療 法の効果：ステロイドおよびAra A 併用療法では, seronegative, seroconversion した症例は 9 例中 4 例 (44\%)，ステロイトホルモン単独群では 7 例中 3 例 (42\%)，T.F. 投与群では17例中 4 例 (26\%) であり， ステロイドおよびAra A 併用群, ステロイド単独群で は, seronegative, seroconversion 率は高値を示した。 またこれら治療により肝機能検查の schubのみられ たものはステロイドおよびAra A 併用群では 9 例中

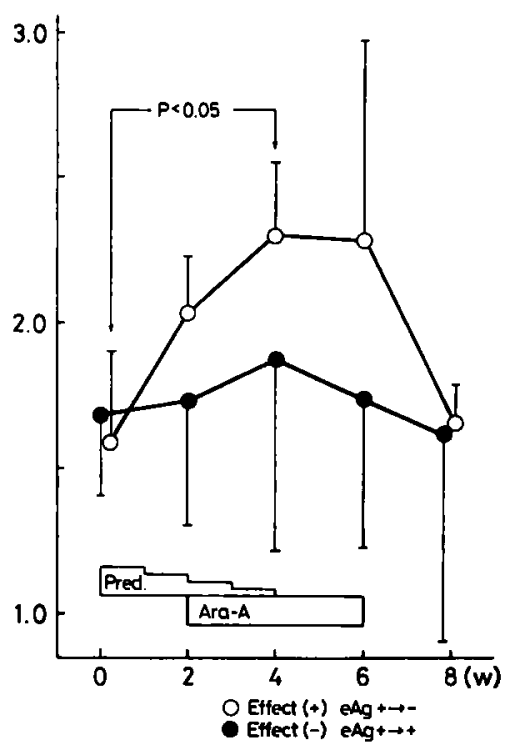

Fig. 2 ステロイドホルモン, Ara A 投与時における $\mathrm{T}$ cell subsets $の$ 推移.

\section{Case S.0. 33 y.o. male}

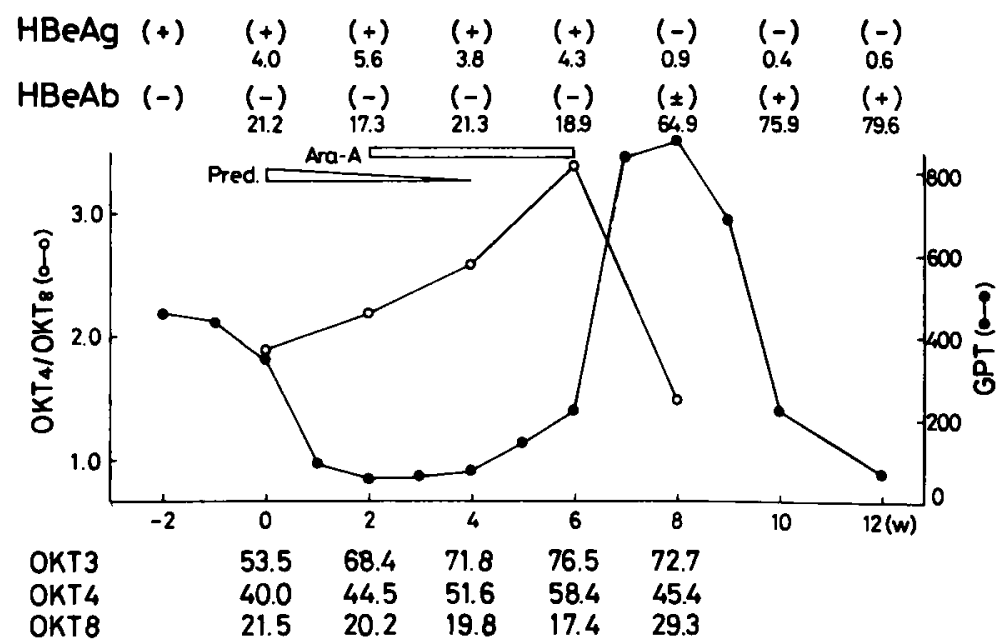

Fig. 3 ステロイドホルモン, 扎よびAra A 投与時の慢性活動性肝资症例時の T cell subsets の推移. 
7 例 $(80 \%)$ ，ステロイドホルモン単独群では 7 例中 5 例 (70\%)，T.F. 投与群では17例中 5 例 (30\%) であっ た.

3）ステロイドホルモンおよびTF投与前後におけ る末梢血 $\mathrm{T}$ cell subsetsの推移：各種治療法により seronegative, seroconversionする症例では, Tリン パ球がどのような動態を呈するかについて，末梢血 T cell subsetsについて検討した，TF投与前後における 末梢血 T cell subsets では, OKT 3 , OKT 4, OKT 8 に著変を認めなかったが, OKT 4/OKT 8 比は，投与 前 $1.3 \pm 0.2$ から，投与後 $1.6 \pm 0.15$ と上昇する傾向を示 L，T.F. 投与により e 抗原から e 抗体に seroconversion 2 例では, 1 例は OKT 4/OKT 8比は1.5か.ら2.0 へ，他の 1 例では0.5から1.5と上昇を示した。 ステロ イドホルモンおよびAra A 投与前後における末梢血
T cell subsetsにおいても，Fig. 2 に示すごとく，投 与前值との変動幅では，有効例ではOKT 4/OKT 8 比 は 4 週間後に有意の増加を示したのに比し，無効例で は 8 週間後まで前値と比較して有意の増加を示さな かった．代表例を呈示すると，Fig. 3に示すように schub と注注同時期にOKT 4/OKT 8比も上昇を示 し， e 抗体への seroconversionがみとめられた。 ステ ロイドホルモン単独群でも，OKT 4/OKT 8比は同様 の動態を示した。

\section{まとめ}

以上の成樍より, e 抗原 $か$ i seronegative, seroconversion 寸る症例では, suppressor T cell Killer T cell などの host の免疫反応が重要な要因となってい る可能性が推測された。

\section{B 型慢性肝资の病態と治療効果 一特にウイルス感染防御機構（2-5A system）からみた評価}

黒木 哲夫 針原 重義 西口 修平 （大阪市立大学第三内科）

B 型慢性肝炎の治療効果は，その病態によりかなり 規定されていることが明らかになってきた，著者は $\mathrm{HBe}$ 抗原陽性慢性肝炎の病態と治療効果との関連性 を解析する目的で，特に $2^{\prime}, 5^{\prime}$-oligoadenylate synthetase（2-5 AS）を指標にウイルス感染防御機構 の観点から検討した。

\section{方 法}

血中 HBe 抗原・抗体は RIA·EIA にて測定し，肝組 織 $\mathrm{HBc}$ 抗原はPAP 法にて染色し $1 \mathrm{~mm}^{2}$ 当りの $\mathrm{HBc}$ 抗原陽性肝細胞数を 5 力所数之，その平均値を $\mathrm{HBc}$ 抗原 score とした．2-5AS 活性は Kerr ${ }^{13}$ の変法招よび 2-5AS 測定用 Kit (栄研化学 KK) にて測定し，患者り ンパ球サブセットは two-color flow cytometryにて 測定した。

\section{成 縝}

B 型慢性肝炎の代表的治療薬として，インターフェ ロン(IFN)，副腎皮質ステロイド，組換え型インター ロイキン2（r-IL2）について娭討した.

I. インターフェロン (IFN)

IFNによるヒト末梢血単核細胞（PBMC）の2-5AS
誘導能を in vivo, in vitro に測定し，病㦔との関連を 検討した。

1）病態による2-5AS 誘導の美異：IFN 投与または 添加・培養により PBMC の2-5AS 活性は全例で有意 に增加し，IFNによるウイルス感染防御機構の作動が 確認された.しかしながら IFN による2-5AS 誘導には 健常人においても個体差がみられ，また肝疾患の病態 による差異も顕著であった。病型別では慢性活動性肝 炎において2-5AS 誘導は良好で，またトランスアミ ナーゼ高值例および肝組䅱 HBc 抗原 score 低值例に おいて良好であった，2）in vitroに括ける2-5AS 誘導 能と治療効果：IFN 投与前患者 PBMC の2-5 AS 誘 導能を低，中，高誘導群の三段階に区分し，治療奻果 との関連をみた. 高誘導群 3 例は全例 IFN 投与終了後 1 年以内に $\mathrm{HBe}$ 抗原持続陰性化をみた。中等度誘導 5 例では $\mathrm{HBc}$ 抗原低值例に $\mathrm{HBe}$ 抗原持続陰性化を みたが, $\mathrm{HBc}$ 抗原 score 高值例は一過性の陰性化にす ぎなかった。一方，低誘導 5 例では HBc 抗原 score の 多宾にかかわらず全例 $\mathrm{HBe}$ 抗原持続陽性を示した. 以上, 今回の検討成績からはIFN の治療効果を規定す 
る病態として，宿主の2-5AS 誘導能と感染ウイルス量 が極めて重要と考えられた（Fig. 1).

\section{II. 副監皮梊ステロイド}

ステロイド離脱療法では，離脱後の抗体産生能（抗 TNP-SRBC・PFC）の回復が良好な例に治療有効例が 多い成績を既に報告した。今回は本療法におけるウイ ルス感染防御機構の作動状態について検討した。

患者 PBMC の2-5AS 活性はステロイド投与により 急速に低下し，减量・離脱に伴い回復した。一部症例 で投与前值以上の活性を示寸例がみられたが, IFNに 比し2-5AS 誘迋は極めて低値であった。この成績はス テロイド離脱療法ではウイルス感染防御機構より, 宿 主の免疫応答がより重要であることを示唆する。

\section{III. recombinant IL2}

r-IL2 250 - 1000Takeda U/日を HBe 抗原陽性慢性 肝炎に 7 - 28日間投与し, その臨床的影響を検討した。

1) 臨床所見：r-IL2投与のB型慢性肝炎では投与 1ー2 週目に血清トランスフミナーゼの上昇を示し， その後改善する例が多くみられた。この現象は特にト ランスフミナーゼ高值例に顕著であった，2） HBV マーカー：DNA-P活性はr-IL2投与後に低下・陰性化 する例が多くみられたが, その減少速度はIFN に比し 緩徐であった．3）免疫学的所見：r-IL2投与により末 梢血リンパ球サブセットの日内変動では, 点滴終了時

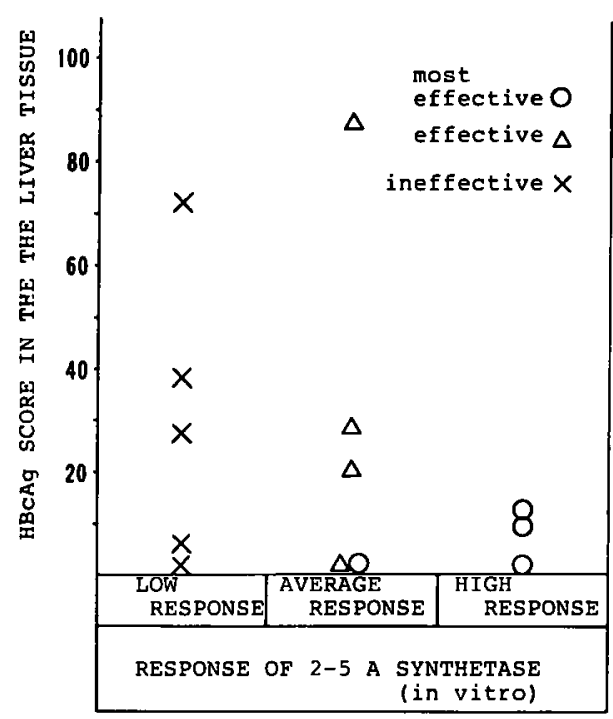

Fig. 1 The relation among the in vitro responses of 2-5A synthetase, $\mathrm{HBcAg}$ score and the efficacy of IFN therapy (Most effective cases who became negative for $\mathrm{HBeAg}$ in serum within one year. Effective cases who became negative for $\mathrm{HBeAg}$ in serum after one year or transiently negative. Ineffective cases who had persistent $\mathrm{HBe}$ antigenemia.)
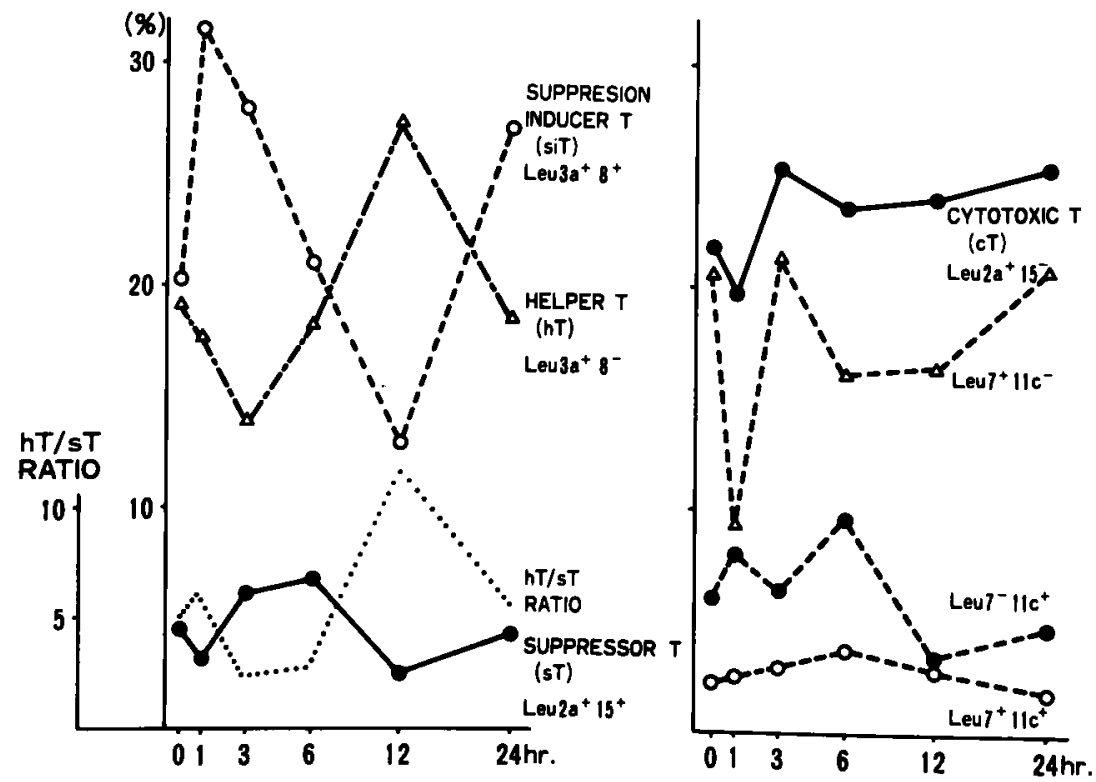

Fig. 2 Changes of lymphocyte-subsets in a patient with chronic active hepatitis after intravascular injection of 500 Takeda U r-IL2. 


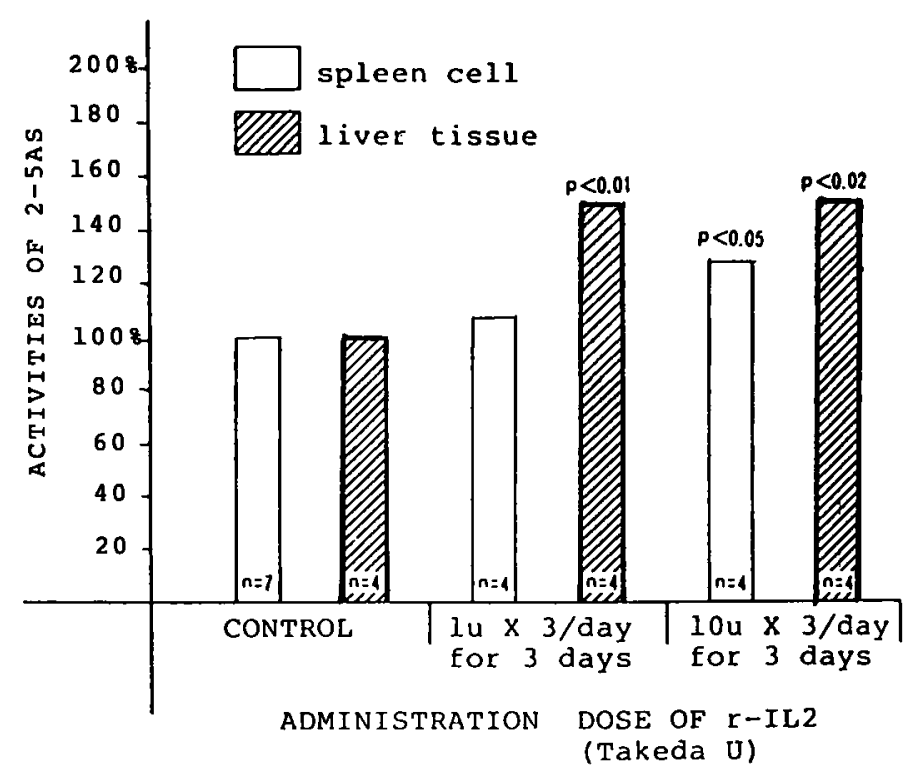

Fig. 3 Activities of 2-5A synthetase in murine spleen cell or the liver tissue after r-IL2 injection to abdominal cavity.

に Leu $3 \mathrm{a}^{+} \cdot 8^{+}$(suppresion inducer $\mathrm{T}$ ) 拉よび Leu $2 \mathrm{a}^{+} \cdot 15^{+}$(suppressor T) の一過性増加がみられ, negative feed back の作動が示唆された. しかし Leu $3 \mathrm{a}^{+} \cdot 8^{+}$の减少に伴い, Leu $3 \mathrm{a}^{+} \cdot 8^{-}$(helper T), Leu 2 $\mathrm{a}^{+} \cdot 15^{-}$(cytotoxic T), Leu $7^{-} \cdot 11 \mathrm{c}^{+}$(活性化 NK) の増加が著明で, r-IL2による免疫活性化が認められた (Fig. 2).4）ウイルス感染防御機構の作動：r-IL2をマ ウス腹腔内に 1 回 1 - 10U ( 1 日 3 回) ・ 3 日間投与 し, 脾細胞および肝組織中2-5AS 活性を測定した。 2-5 AS 活性は 1 回10U 投与群の脾細胞および 1 回 1 10 U 投与群の肝組織において有意の増加を示し, $r$-IL2に よるウイルス感染防御機構の作動が認められた。しか しr-IL2 500〜750U 日投与の患者 PBMCでは同活性 の増加は検出されなかった。 また r-IL2 $0.1 \mathrm{U} / \mathrm{m} l$ 添 加・培䍹のPBMCに打いても同活性増加は2.3倍にす ぎず，IFN 1.000U添加培盖の約 $1 / 4$ の活性にすぎ かった。

以上のヒト PBMCの r-IL2添加培盖成績から, 現在 の臨床投与量の範囲内では r-IL2の2-5AS 誘導は IFN に比し弱く, r-IL2投与の効果としてはウイルス感染防
御機構の作動よりむ免疫賦活作用が中心的役割をはた しているむのと考えられた。

象引用語: $2^{\prime}, 5^{\prime}$ oligoadenylate synthetase, interferon therapy, recombinant interleukin 2 (r-IL2)

$$
\text { 文献 }
$$

1) Hovanessian AG, et al: Enzymic synthesis, purification and fraction of $\left(2^{\prime}-5^{\prime}\right)$. oligoadenylic acid. Methods in Enzymology 79 : 184, 1981, Academic Press, New York.

2）黒木哲夫, 西口修平, 他：B 型肝炎ウイルスに関す 万免疫応答一予防・治療への臨床応用. 臨床免疫 16 (suppl 8) : 41, 1984

3）西口检平，黒木哲夫，他：Interferon 投与 B 型僈 性肝炎患者の末梢血単核細胞における2', $5^{\prime}$ oligoadenylate synthetase 活性の推移. 訮䁍 $25: 416,1984$

4）黒木哲夫，西口修平，他：Interferon 投与動物の肝 組織における $2^{\prime}, 5^{\prime}$ oligoadenylate synthetase 活 性について。肝䐬 $25: 417,1984$

5）黒木哲夫, 西口侦平, 他：抗ウイルス療法. 消化器 疾患の基礎之臨床, 山本祐夫, 小林絢三編, メディ カルレビュー社, 東京, 1985, p16 


\title{
B 型慢性肝资の肝組織中 HBV および細胞性免疫に及ほすす 抗ウイルス剤の治療効果について
}

\author{
山田剛太郎 真鍋 康二 長島 秀夫 \\ (岡山大学第一内科)
}

B 型慢性肝炎症例において Interferon（IF）ないし はAra・Aによる抗ウイルス療法が肝炎の病態に及ぼ す効果を明らかにするために，投与前後の肝生検を利 用して, 肝組織中の B 型肝炎ウイルス (HBV) 関連抗 原ならびに細胞性免疫応答について免度組織学的に検 討したので報告する.

\section{対象と方法}

対象は B 型慢性肝炎で特殊な治療を受けていない 患者115例とIF ないしはAra・A の投与を受けた患者 でかつ投与前後に肝生検の実施できた29例である，IF またはAra・Aの治療を受けた患者はいずれる血中 $\mathrm{HBe}$ 抗原陽性で，投与前 1 - 2 力月と投与終了後 1 力 月前後の 2 回肝生検を実施した。 IF- $\beta$ を 5 例 ( 3 例は 600 万 u. $\times 7$ 日，300万 u. $\times 21$ 日を，2 例はさらに 300 万 u.を隔日に 5 力月間長期投与), recombinant IF- $\alpha$ を 6 例（1,800万 u. $\times 28$ 日), human lymphoblast IF- $\alpha$ （HLBI）を14例（600万 u. $\times 28$ 日を1クールとし，1 クールのみ 7 例, 他の 7 例は 1 カ月の休薬期間を拈い て 3 クール投与), Ara・A を 4 例 ( 3 例に $10 \mathrm{mg} / \mathrm{kg} \times$ 21日. 1 例に $10 \mathrm{mg} / \mathrm{kg} \times 7$ 日, $5 \mathrm{mg} / \mathrm{kg} \times 21$ 日を 2 週間 の休薬期間をおいて 2 回投与) に使用した。肝生検組 織は通常の光顕用はBouin 液で, 免疫組織用はPLP 液で固定した. HBs 抗原, HBc 抗原は horseradish peroxidase (HRPO) で標識した HBs 抗体と HBc 抗 体”を用いて醅素抗体直接法で同定した。リンパ球 subset の分別は抗 Leu-1 (pan $T$ cell), 抗 Leu-2a (cytotoxic/suppressor T cell), 抗 Leu-3a (helper/ inducer $\mathrm{T}$ cell), 抗 Leu-7 (natural killer/K cells), 抗 Leu-15 (suppressor T cell) の各モノクローナル抗 体)（Beckton·Dickinson 社）を，HLA-class 1 抗原 の同定には抗 HLA ・ABC 抗体 ${ }^{3)}$ (Cappel 社)をいず れも 1 次抗体として醭素抗体間接法で観察した。組織 中 $\mathrm{HBc}$ 抗原, HBs 抗原は半定量的に0 IVの 5 段階4 に, 血中 DNA ホリメラーゼ活性 (DNA-P) む+4 $(5,000 \mathrm{CPM}$ 以上), $+3(1,000 \leqq,<5,000 \mathrm{CPM}),+2$ $(500 \leqq,<1,000 \mathrm{CPM}),+1(<500 \mathrm{CPM}),-$ の 5 段階 に分類した。 また，肝細胞表面の HLA-class 1抗原は
陰性のものを normal (N)とし, 陽性のものは+1(弱) と+2(強)の 2 段階に分けた.

\section{成 績}

B 型慢性肝炎の未治療例36例で肝生検時に血中 DNA.P を測定し、旰組織中の $\mathrm{HBc}$ 抗原との関連を比 較したが，両者はほぼ相関した。しかし，血中DNAP 500CPM 以下の低値ないしは陰性の症例の一部で は HBc 抗原陽性の肝細胞が小葉によっては集皦して 観察される部分も認められ, 肝内 $\mathrm{HBc}$ 抗原は $\mathrm{HBV}$ の active replicationのより良い指標になるものと考 えられた。

IF（4 週間投与）ないしはAra-A（3 週間投与）の 短期間投与前後の血中 DNA-P 括よび肝組織中 HBc 抗原の変動では，血中 DNA-P は低下する例が多かっ たが, 肝内 $\mathrm{HBc}$ 抗原は DNA.P と平行して減少する 例も認められたがむしろ不変の例の方が多かった (Fig. 1). 一方, $\beta$-IF ないしは HLBI の長期投与例で は，投与後血中 DNA.P の陰性化とともに肝組織中の $\mathrm{HBc}$ 抗原む明らかに减少している例が多く認められ

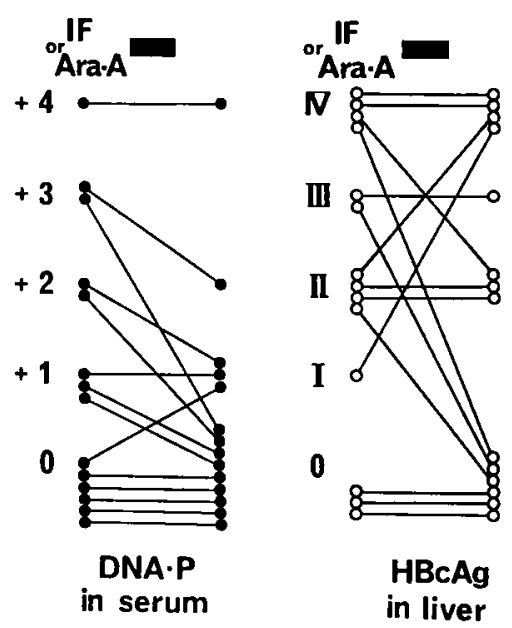

Fig. 1 Change of DNA-polymerase activity in sera and intrahepatic $\mathrm{HBcAg}$ in patients with chronic hepatitis $B$ before and after treatment of interferon (4 weeks) or Ara-A (3 weeks). 


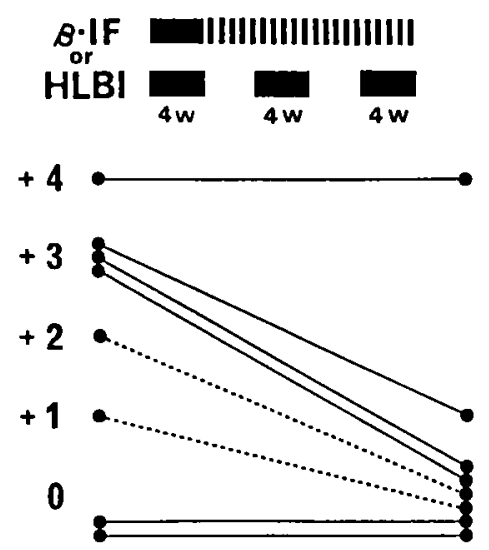

DNA.P in serum

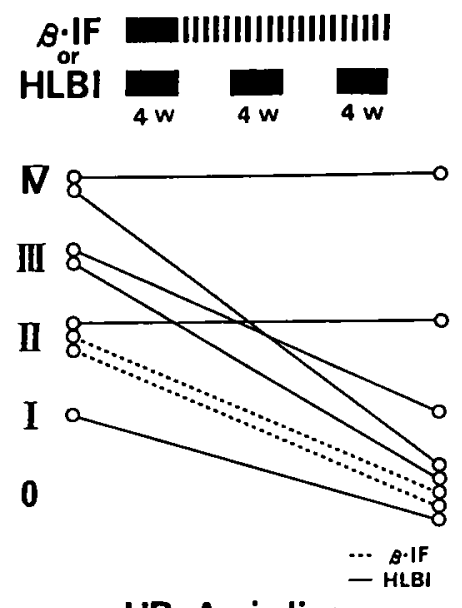

$\mathrm{HBcAg}$ in liver

Fig. 2 Change of DNA-polymerase activity in sera and intrahepatic $\mathrm{HBcAg}$ in patients with chronic hepatitis $B$ before and after treatment of $\beta$-interferon (every day for 4 weeks and every other day for 5 months) or human lymphoblast interferon- $\alpha$ ( 4 weeks $\times 3$ ).

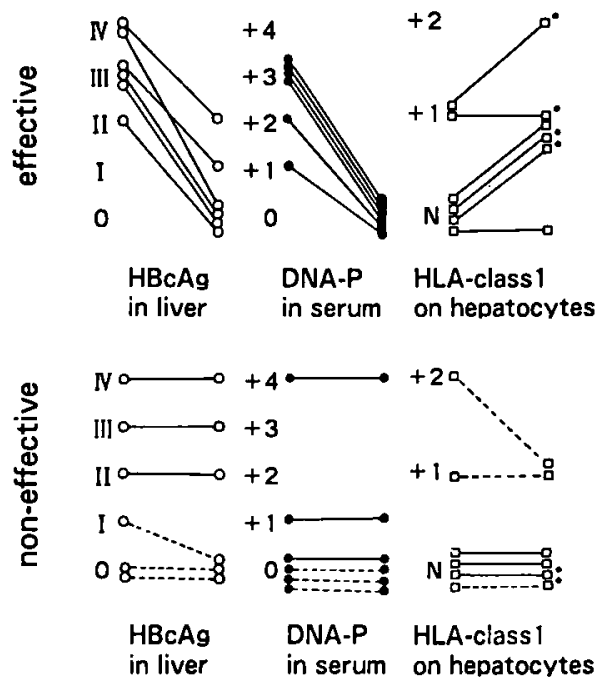

Fig. 3 Change of HLA-class 1 antigens on he. patocyte in an effective group (both intrahepatic $\mathrm{HBCAg}$ and sero-DNA.P are markedly decreased) and in a non-effective group (both intrahepatic $\mathrm{HBcAg}$ and sero-DNA-P are stationary) before and after treatment of interferon. *treated with interferon for long duration.

た (Fig. 2).

HLA-class 1抗原がIF 投与前後で検索できた12例 のうち, 肝内 $\mathrm{HBc}$ 抗原および血中 DNA-Pが IF 投与 後に明らかに減少した（effective）群では 6 例中 4 例
で肝細胞表面の HLA-class 1抗原の表出の増強が観察 された (Fig. 3)。しかし，肝内 $\mathrm{HBc}$ 抗原拉よび血中 DNA-P の不変 (non-effective) 群では HLA-class 1抗 原も不変ないしは減少傾向が認められた（Fig. 3).

肝組織中の浸潤リンパ球は小葉内と門脈域の面積あ たりの実数を数えて比較したが，投与終了後 $\mathrm{HBc}$ 抗 原陽性肝細胞の著减した例では, cytotoxic $\mathrm{T}$ cell (Leu-2a + , Leu-15-) $\gg \mathrm{NK} \cdot \mathrm{K}$ cells (Leu-7+) の 明らかな减少が認められた。

\section{考察およひ結語}

IF は B 型慢性肝炎症例に括ける投与経過より，血 中 DNA-Pの減少のみでなく，肝組織中の HBV 感染 肝細胞も明らかに減少させていることが判明したが, 4 週間の短期投与に比して, 半年間の長期投与の方で その努果は顕著であった。このような抗ウイルス効果 の機序としては単に HBVの active replicationを抑 制するのみでなく，種々の免疫応答への IF の作用機 序が考えられる. in vitroの成績では細胞表面の HLA-class 1 抗原の表出を増強させる作用”ゃ cytotoxic T cell やNK cell に作用して兔疫応答を高 めることが知られている. 今回の検討では， $\mathrm{HBc}$ 抗原 陽性肝細胞が著明に減少した症例で肝細胞表面の HLA-class 1抗原の増強が観察される例が多く，これ らの所見はIF が肝細胞表面の HLA-class 1抗原の表 出を高め, cytotoxic T cell による HBV 感染肝細胞 の排除を促進した可能性を強く示唆している. 
索引用語：B 型慢性肝炎の治療, 抗ウイルス剂、イ ンターフェロン

\section{文献}

1) Yamada G, Sakamoto $Y$, Mizuno M, et al : Electron and immunoelectron microscopic study of Dane particle formation in chronic hepatitis $B$ virus infection. Gastroenterology $83: 348-356,1982$

2) Yamada G, Nishihara T, Hyodo I, et al : Cellular immune response in liver of patients with chronic hepatitis B. Gastroent Jpn $19: 517$ $-528,1984$
3) Manabe K, Yamada G, Nagashima H : Immunohistochemical study of HLA class 1 antigens on the hepatocytes of patients with chronic hepatitis B. Gastroent Jpn 21 : 357-364, 1986

4）山田剛太郎, 真鍋康二, 兵頭一之介, 他 : B 型肝炎 ウイルスと $\delta$ 因子，肝胆膵 $11: 943-953 ， 1985$

5) Heron I, Hokland M, Berg K: Enhanced expression of 2-microglobulin and HLA antigens on human lymphoid cells by intreferon. Proc Natl Acad Sci USA 75:6215-6219, 1978

\title{
B 型慢性肝炎患者に対するインターフェロン長期間久投与
}

\author{
金井 弘一 中島 猛行 石井 英正 \\ （浜松医科大学第二内科）
}

目的

e 抗原陽性の B 型慢性肝炎患者に対するインター フェロン間欠投与の効果を血中ウイルスマーカーおよ び免疫ハラメーターの面から検討する。

$$
\text { 対象 }
$$

e 抗原陽性の B 型慢性肝炎患者28例ですべて男性で あり，平均年龄31.6歳である。

\section{方 法}

インターフェロン（IFN, recombinant IFN- $\alpha$, 日 本ロシュ）の投与方法は週 2 回の間欠投与とし, A 群 (5 例) は 1 回量600万単位を 3 カ月間合計 14,400 万単 位を, B 群 ( 7 例) は 1 回量900万単位を 3 力月間合計 21 ,600万単位を投与した。C 群(16例)は併用群で, IFN 1 回量300万単位と cyanidanol 2,250mg/日を 6 カ月 間併用した. IFN 投与はすべて外来で行った．血中 HBs 抗原, HBs 抗体, HBe 抗原, HBe 抗体は RIA 法 で, DNAポリメラーゼ (DNA-P) は Kaplanの変法 でそれぞれ测定した：末梢血リンハ球表面マーカーの 解析はモノクローナル抗体 (OKTシリーズ, オルン 社）を用いて行った。

\section{成}

血中 DNA-P 活性, HBe 抗原値は治療開始とともに 低下したが，治療終了後に一過性に上昇する例がみら れた。治療終了後 6 力月の時点での $\mathrm{HBe}$ 抗原陰性化 は A 群では 1 例む認められなかったが, B 群では 7 例
中 5 例 (71\%)，C群では13例中 4 例 (31\%)に HBe 抗 原が陰性化していた (Table 1).トランスアミナーゼ 值むIFN 投与開始後すみやかに改善したが, 投与終了 後に再上昇する例が多く，数カ月にわたりトランスフ ミナーゼの動摇を反復する例るみられた。

末梢血リンパ球表面マ一カ一の変化を，C群のうち e 抗原陰性化群 (有効群, responder, 4 例) と e 抗原 持続陽性群 (無効群, nonresponder, 8 例) について 検討した。有効群では無效群に比して治療前の OKT 3 陽性細胞 $(\mathrm{p}<0.05) ， \mathrm{OKT} 4$ 陽性細胞 $(\mathrm{p}<0.01) ， \mathrm{~T} 4$ / T8比（p<0.05）がいずれる有意に低下していたが, OKT 8陽性細胞やOKIa1陽性細胞は両者間に差はな かった (Fig. 1). 有効群では IFN 投与ととるにOKT 4陽性細胞数が増加し，それに伴いT4/T8比も上界し

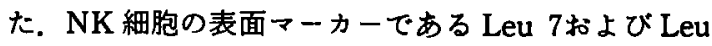

Table 1 Results of IFN treatment.

\begin{tabular}{c|c|c|c|c}
\hline \multirow{2}{*}{ group } & \multicolumn{4}{|c}{ months after initiation of IFN therapy } \\
\cline { 2 - 5 } & 3 & 6 & 9 & 12 \\
\hline \multirow{2}{*}{$\mathrm{A}$} & $0 / 5$ & $0 / 5$ & $0 / 5$ & - \\
& $(0 \%)$ & $(0 \%)$ & $(0 \%)$ & \\
$\mathrm{B}$ & $5 / 7$ & $5 / 7$ & $5 / 7$ & - \\
& $(71 \%)$ & $(71 \%)$ & $(71 \%)$ & - \\
$\mathrm{C}$ & $2 / 16$ & $3 / 16$ & $3 / 14$ & $4 / 13$ \\
& $(13 \%)$ & $(19 \%)$ & $(21 \%)$ & $(31 \%)$ \\
\hline
\end{tabular}

No. of cases who turned to eAg-negative/No. of cases treated with IFN 


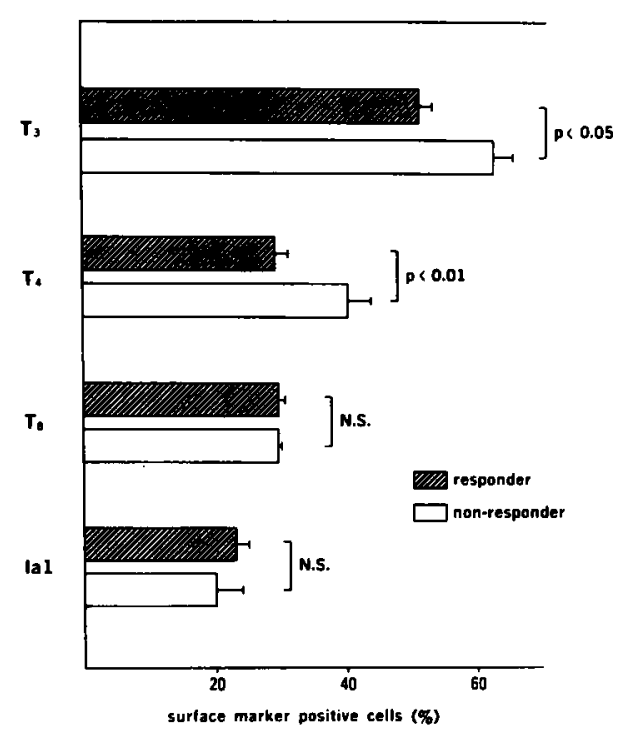

Fig. 1 Surface markers of peripheral blood lymphocytes defined by monoclonal antibodies among responders and non-responders before treatment. Figures in parenthesis indicate percentage of the patients who turned eAg-negative.

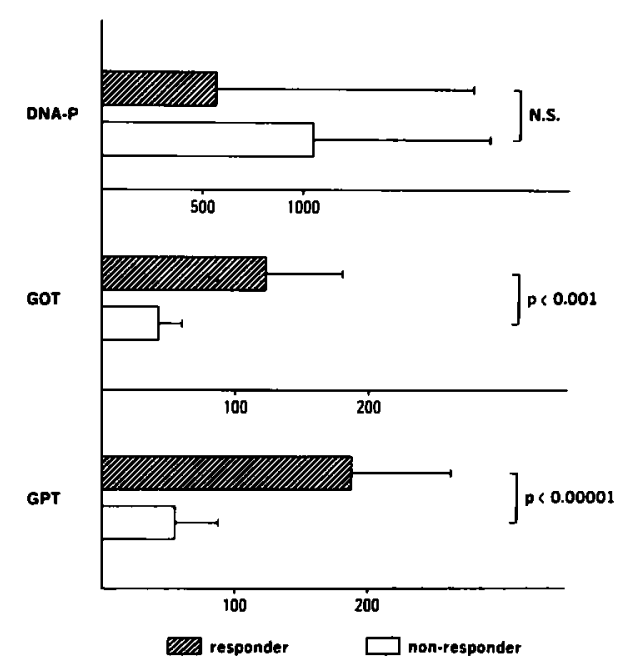

Fig. 2 Pre-treatment level of serum DNA.P, GOT and GPT in responders and non-responders to IFN therapy.

11a 陽性細胞は有効群, 無効群の間に差はなく, IFN 投 与前後においても有意の変化は認められなかった。

つぎに治療効果と IFN 投与開始時の DNA-P，トラ ンスフミナーゼ值との相関について検討した. DNA.P は有効群と無効群の間に差はなかったが, GOT（p<
0.001), GPT ( $\left.\mathrm{p}<10^{-5}\right)$ ともに有効群で明らかに高値 であり (Fig. 2), 治療開始時 GPT 100単位以上の症例 10例中 6 例で治療後 $\mathrm{e}$ 抗原が消失したのに対し, GPT 99単位以下では16例中 2 例で e 抗原陰性化をみたのみ であった。

副作用として発熱は全例にみられ最高 $39^{\circ} \mathrm{C}$ に達し た. 全身供怠感も過半数の症例に出現した。白血球减 少，血小板减少など骨䯣抑制は軽度でいずれも治療中 に改善傾向を示した。ほかに重大な副作用はなく，患 者は通常の社会生活を営みながら治療をらけることが 可能であった。

\section{考案および結論}

Greenberg ${ }^{1)}$ らの報告以後 B 型慢性肝炎に対する IFN 投与が試みられている.しかしながら従来行なわ れてきた 4 週間連日投与法の成績は当初の期待とはほ ぞ遠く，また副作用をはしめ患者に与える苦痛も少く ない。われわれはIFN の治療効果を高めるとともに患 者の負担をる軽减する目的から外来におけるIFNの 長期間欠投与を試みた．A 群では有効例がなかったも のの，B群では 7 例中 5 例，71\%に，またC群です 13 例中 4 例， $31 \%$ e 抗原消失をみた。有効群ではリン 八球サブセットの5ちで OKT 4陽性細胞が治療前か ら減少しており，へルパーT 細胞機能の低下が推測さ れた。有効例で IFN 投与後にみられる OKT 4 陽性細 胞の増加は, IFN が T 細胞系に対する免度䟼活作用を 介してe 抗原陰性化をむたらす可能性を示唆してい る.さらに今回の成績では治療開始時のトランスアミ ナーゼが高値の症例に有効率が高かった。これらの事 実から IFN 投与にさいしては症例の選択や治療開始 のタイミングが重要であると思われる。

最近 B 型慢性肝炎に対するIFN 間欠投与（週 3 回） が欧米で開始され，pilot study の段階ではあるが従来 の投与法に比して有効率の高いことが報告されてい $3^{2 \sim 4)}$.

投与法も含めてまだ娭討すべき点は多く残されては いるか， B 型慢性肝炎に対するIFN 間欠投与はその有 効性のみならず，副作用の少い点さらに外来投与が可 能で患者に与える負担が少い点などからす今後有望な 治療法と考えられる。

卖引用語：インターフェロン, B 型慢性肝炎, 間欠 投与

\section{文献}

1) Greenberg HB, Pollard RB, Lutwig LI, Gregory PB, Robinson WS, Merigan TC: Effect of 
human leukocyte interferon and hepatitis B virus infection in patients with chronic active hepatitis. N Engl J Med 295: 517-22, 1976

2) Dusheiko G, Dibisceglie A, Bowyer S, Sachs E, Ritchie M, Schoub B, Kew M: Recombinant leukocyte interferon treatment of chronic hepatitis B. Hepatology $5: 556-560,1985$

3) Lok AS, Novick DM, Karayiannis P, Dunk AA, Sherlock S, Thomas HC: A randomized study of the effects of adenine arabinoside $5^{\prime}$. monophosphate (short or long courses) and lymphoblastoid interferon on hepatitis $B$ virus replication. Hepatology $5: 1132-1138,1985$

4) Dooley JS, Davis GL, Peters M, Waggoner JG, Goodman Z, Hoofnagle JH: Pilot study of recombinant human $\alpha$-interferon for chronic type B hepatitis. Gastroenterol $90: 150-157$, 1986

\title{
B 型慢性肝资に対するインターフェロン短期間歇療法について
}

\author{
飯野 四郎* 日野 邦彦** \\ (*東京大学第一内科, **防衛医科大学校第二内科)
}

B 型慢性肝炎に対するインターフェロン(IFN)療法 は Greenberg らの報告'以後10年を経たが，末たにそ の効果が広く認識されるに至っていない.

IFN が B 型肝炎ウイルス (HBV)に対して明らかに 抗ウイルス作用を示すにるかかからず，また，効果判 定基準に問題があるにしても，今一つ作用が顕著でな いことに原因があるように思われる。

IFNを 4 週間継続投与すると IFN に対する生体の 反応性が低下していることを推察ざせる多くの事実に 遭遇する.このことから，4週間連続投与した場合に， IFN が本来の抗ウイルス効果を示していないのでは ないかとの疑念が生し，この事実を確かめることと生 体の反応性を維持しながら投与する方法を探し出すこ とを目的に以下の試みを行った。

\section{方法およひ対象}

$\mathrm{HBe}$ 抗原陽性の慢性活動性肝炎を対象として, IFN 4 週間継続投与群（継続投与群）および 1 週間継続投 与, 1 週間休薬のサイクルを $6 \sim 8$ 回繰り返した群(短 期反復投与群)につき，IFN 投与前， 3 時間・ 6 時間・ 12 時間・24時間後の諸点および投与前，投与開始後各 週の諸点で,一般生化学, 末梢血液像, リンハ球機能, リンパ球サブセット，HBVマーカーなどを検討した。

\section{成績およひ考案}

\section{IFN 投与24時間内の諸検査成績の变動}

血清総蛋白量, フルブミン値, 総コレステロール值 およびュリンエステラーゼ活性は1.5〜3 時間後には 前値の60～70\%に低下し，12時間後からやや回復する が24時間後までには前値まで回復しきれない，連日継
続投与した場合ここの変化はその度毎に繰り返される が, 初回投与 24 時間後の值から毎日さらに低下し，ほ ぼ同じ值に戻るといらサイクルである．たた変動幅は 継続投与で縮小寸る傾向がある。

白血球数の変化は主として好中球とリンパ球の変化 によるものである.好中球は投与1.5－3 時間では前值 より増加するがその後は減少し，24時問後にはやや回 復する.リンパ球は投与1.5〜 3 時間で最低值となり， その後は増加し，18時間前後に最高值となり，前值を 上回った後, 減少し，24時間後には前値に復する．継 続投与するとこの変動幅は徐々に小さくなる.

リンバ球機能はPHA, Con A 刺激でみた場合,リ ンハ球数の変動とほぼ同様の動きを示す.PWM 刺激 ではほとんど変動はみられない。

NK 活性は投与後低下して，6時間後に最低值とな り，その後上昇して，24時間後には前値を越える．継 続投与した場合には变動幅が縮小するとともに最高値 も 1 週間を過ぎると低下傾向を示す. Leu 7, Leu 11a 陽性細胞むNK 活性とほぼ同じ変動を示す。

OKT4 陽性細胞は投与後上梨し，24時間後前値以上 となる。この変動を繰り返し，2週間は上昇するが， その後は変動幅の縮小, 最高値の低下がみられる. OKT4 陽性細胞の変化はリンパ球のそれと同じであ ๖.

このよらにIFN 投与により多くのものが速やかに 変動するが，これは生体内分布の変化によると考えら れる.また，いずれの変化も 1 一 2 週を過ぎると变動 幅が縮小するがこれは生体の反応性低下を示するのと 


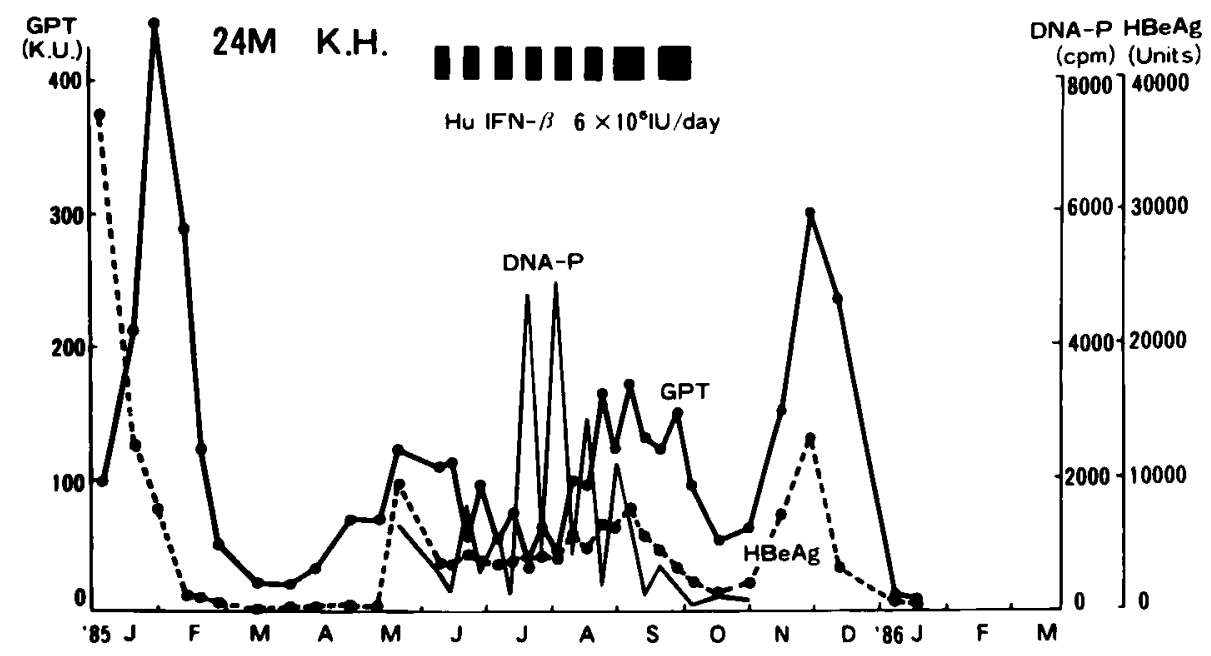

Fig. 1 A case of 1 week short-term IFN cycle therapy.

Table 1 Changes in $\mathrm{HBeAg}$ and alanine aminotransferase after short-term IFN cycle therapy.

\begin{tabular}{|c|c|c|c|c|c|c|c|c|}
\hline \multicolumn{2}{|l|}{$\begin{array}{l}\text { after } \\
\text { treatment }(M)\end{array}$} & 0 & 1 & 2 & 3 & 4 & 5 & 6 \\
\hline \multicolumn{2}{|l|}{ Case No. } & 13 & 13 & 13 & 13 & 12 & 11 & 11 \\
\hline \multirow{3}{*}{$\mathrm{HBeAg}$} & - & 7 & 4 & 4 & 5 & 5 & 5 & 5 \\
\hline & \pm & 0 & 0 & 1 & 2 & 4 & 3 & 2 \\
\hline & + & 6 & 9 & 8 & 6 & 3 & 3 & 4 \\
\hline \multicolumn{2}{|l|}{ GPT normalized } & 6 & 5 & 5 & 6 & 8 & 8 & 8 \\
\hline
\end{tabular}

考えられる。

\section{IFN 継続投与時の諸成績の変化}

白血球数，好中球数は初め低下したままの值が投与 中継続し，リンパ球数は殆んど不変である。OKT4は 上昇したままの値が続くが, OKT8は不変である.NK 活性は 1 週目を最高に徐々に低下し，PHA・Con Aに よる幼若化反応は 2 週目を最高に低下する，2'-5'AS 活性は 1 ～ 2 週を最高として低下する.

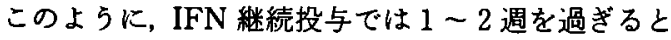
反応性の低下が明らかとなる。

\section{IFN 短期反復投与時の諸成績の変化}

白血球数，好中球数は投与中に低下，休薬中に上㫒 といらサイクルを繰り返すがこの変動も徐々に小さ くなる、リンパ球数は不変である. OKT4, NK 活性は
投与により上昇, 中止により低下するが, NK 活性の場 合上昇度は小さくなる． $2^{\prime}-5^{\prime} \mathrm{AS}$ む NK 活性とほぼ同 じである。

短期反復投与群では投与中止時13例中 7 例で $\mathrm{HBe}$ 抗原の陰性化，6 例で GPT の正常化をみた. 投与中止 6 力月後では11例中 5 例で $\mathrm{HBe}$ 抗原の陰性化, 判定 保留域 2 例をみ, GPTは 8 例で正常化していた (Table 1).その 1 例を Fig. 1 に示した。

$$
\text { 結語 }
$$

1 週間の投薬・休薬のサイクル, IFN 短期反復療法 は従来からの 4 週間の継続投与に比して, 生体の IFN に対する反応性をよく維持することから，より効果的 な IFN 投与法と考えられる。これにより 6 力月後には 11例中 5 例 (45\%) で $\mathrm{HBe}$ 抗原の陰性化, GPT の正 常化をみた。しかし，この投与法であっても生体の反 応性の低下がみられており，さらに投与法の工夫が必 要と考古られる.これによりさらに IFN の効果を高め らると考えられる。

卖引用語：IFN, 短期反復噔法, 生体反応

$$
\text { 文献 }
$$

1) Greenberg HB, Pollard RB, Lutwick LI, et al : Effect of human leukocyte interferon on hepatitis B virus infection in patients with chronic active hepatitis. New Engl J Med 295:517 $-522,1976$ 


\section{B 型肝资の各種治療法の比較検討}

\section{熊田 博光 吉場 朗}

(虎の門病院消化器科)

はじめに

$\mathrm{e}$ 抗原陽性 B 型慢性肝炎に対してステロイド離脱療 法,インターフェロン療法，などの種々の治療法につ いて感染経路および抗核抗体の有無などによる治療成 績を比較検討した。

\section{対象およU方法}

1977年 4 月より1985年 6 月迄，ステロイド離脱療法 を行なった80例，ステロイト離脱＋Ara-A 17例，イン ターフェロン療法13例，クリチルリチン静注療法17例， ステロイド長期療法14例計141例とした。

\section{成}

1）ステロイド単独離脱療法の成績（表 1）。ステロ イド単独離脱療法の治療後 1 年の成縝は, Seroconversion 例は, 80 例中 36 例 (45.0\%), Seronegative 例は, 22 例 $(27.5 \%)$, 計58例 $(72.5 \%)$ ，にe 抗原の 消失，あるいは e 抗体の出現が認められた。これらの 成績を父親母親の感染経過別について検討すると，母 親が HBs 抗原陽性あるいは肝疾患で死亡した症例は 23例父親が HBs 抗原陽性あるいは肝疾患で死亡した 症例は12例で両親共 HBs 抗原が陰性であった症例は
32例，その他不明13例であった，そこで感染経路別の 治療成績について検討した。毑親が HBs 抗原陽性あ るいは肝疾患で死亡した23例中 Seroconversion 例は 5 例 $(21.7 \%)$, Seronegative 例は 5 例 $(21.7 \%)$ で, 23例中10例 (43.5\%) にe抗原の陰性化あるいは，Seroconversionが認められた，父親が HBs 抗原陽性ある いは，肝疾患で死亡した12例では，Seroconversion 例 は 6 例 $(50.0 \%)$, Seronegative 例は 3 例 $(25.0 \%)$, 計 9 例 $(75.0 \%$ ) に Seroconversion あるいは e 抗原の 陰性化か認められた。両親共 HBs 抗原陰性だった32 例では Seroconversion 例17例 (53.1\%), Seronegative 例11例 (34.4\%), 計28例 (87.5\%) にe 抗原 の陰性化が認められた。

2）抗核抗体からみたステロイド離脱療法（表 2). 抗核抗体は，一般には自己免疫疾患に最も多い。しか し, 今回は257例の B 型僈性肝炎について抗核抗体の 陽性率を検討したところ e 抗原陽性例158例中16例に （10.1\%）に抗核抗体が陽性であった。しかし，e 抗原 e 抗体 $(-/$-) いわゆる ewindow 13例では抗核抗体 陰性化例は 1 例むなくまた, e 抗体陽性56例でも抗核

表 1 感染経路別にみたステロイド離脱(単独)療法の成績.（治療 1 年後の成績）

\begin{tabular}{|c|c|c|c|c|c|}
\hline 感染経呂 & 迌原／抗体の変化 & $\begin{array}{c}+/-\rightarrow-/+ \\
(\text { Seroconversion) }\end{array}$ & $\stackrel{+/-\rightarrow-/-}{\text { (Seronegative) }}$ & $+/-\rightarrow+1-$ & 計 \\
\hline \multirow{2}{*}{ 母 親 } & \multirow{2}{*}{$\begin{array}{c}\text { HBs 抗原陽性 } \\
\text { あるいは } \\
\text { 肝疾患死亡 }\end{array}$} & $\begin{array}{c}5 \\
(21.7 \%) \\
\end{array}$ & $\begin{array}{r}5 \\
(21.7 \%) \\
\end{array}$ & \multirow{2}{*}{$\begin{array}{c}13 \\
(56.5 \%)\end{array}$} & \multirow[t]{2}{*}{23} \\
\hline & & \multicolumn{2}{|c|}{$10(43.5 \%)$} & & \\
\hline \multirow{2}{*}{ 父 親 } & \multirow{2}{*}{$\begin{array}{c}\text { HBs 抗原陽性 } \\
\text { あるいは } \\
\text { 肝疾患死亡 }\end{array}$} & $\begin{array}{c}6 \\
(50.0 \%) \\
\end{array}$ & $\begin{array}{c}3 \\
(25.0 \%) \\
\end{array}$ & \multirow{2}{*}{$\begin{array}{c}3 \\
(25.0 \%)\end{array}$} & \multirow[t]{2}{*}{12} \\
\hline & & \multicolumn{2}{|c|}{$9(75.0 \%)$} & & \\
\hline \multirow{2}{*}{ 両親共 } & \multirow{2}{*}{ HBs 抗原陰性 } & $\begin{array}{c}17 \\
(53.1 \%)\end{array}$ & $\begin{array}{c}11 \\
(34.4 \%)\end{array}$ & \multirow{2}{*}{$(12.5 \%$} & \multirow{2}{*}{32} \\
\hline & & \multicolumn{2}{|c|}{$28(87.5 \%)$} & & \\
\hline \multirow{2}{*}{\multicolumn{2}{|c|}{ 不 明 }} & $\begin{array}{c}8 \\
(61.5 \%) \\
\end{array}$ & $(23.1 \%)$ & \multirow{2}{*}{$\begin{array}{c}2 \\
(15.4 \%)\end{array}$} & \multirow{2}{*}{13} \\
\hline & & \multicolumn{2}{|c|}{$11(84.6 \%)$} & & \\
\hline \multirow{2}{*}{\multicolumn{2}{|c|}{ 計 }} & $\begin{array}{c}36 \\
(45.0 \%) \\
\end{array}$ & $\begin{array}{c}22 \\
(27.5 \%)\end{array}$ & \multirow{2}{*}{$\begin{array}{c}22 \\
(27.5 \%)\end{array}$} & \multirow{2}{*}{80} \\
\hline & & \multicolumn{2}{|c|}{$58(72.5 \%)$} & & \\
\hline
\end{tabular}


表 2 ANA 陽性群，陰性群別にみた B型慢性肝资の 各種治療成績 (e 抗原陰性化率).

I) Steroid 潅脱 $(+$ AraA $)$

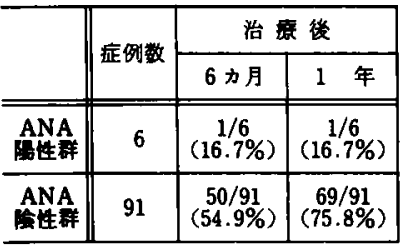

II) インターフェロン

\begin{tabular}{|c||c|c}
\hline & 症例数 & $\begin{array}{c}\text { 治撩後 } \\
1\end{array}$ \\
\hline \hline $\begin{array}{c}\text { 年 } \\
\text { ANA }\end{array}$ & 2 & $0 / 2$ \\
\hline $\begin{array}{c}\text { ANA } \\
\text { AN群 }\end{array}$ & 11 & $\begin{array}{c}4 / 11 \\
(36.4 \%)\end{array}$ \\
\hline
\end{tabular}

抗体陽性例は，1 例も認められなかった。そこでこの 抗核抗体とステロイド離脱療法及びインターフェロン 療法の e 抗原陰性化率の関係をみるため治療後 6 力月 及び 1 年後の $\mathrm{e}$ 抗原陰性化率について検討した。 ステ ロイド離脱療法及び，ステロイド+Ara-Aの併用療法 を行なった97例中の抗核抗体陽性例は 6 例で，そのう ち $\mathrm{e}$ 抗原が陰性化したのは 6 カ月後で 6 例中 1 例 (16.7\%)，1 年の時点で 6 例中 1 例 (16.7\%) であっ た. 一方抗核抗体陰性例91例では， 6 カ月の時点で91 例中50例(54.9\%)で 1 年の時点で91例中 69 例 (75.8\%) と抗核抗体陰性例ではステロイド離脱療法により高頻 度にe 抗原の陰性化が認められた。また,インターフェ ロン療法13例についても同様の検討を行なったところ 抗核抗体陽性例 2 例ではいずれる e 抗原陰性化は認め られず抗核抗体陰性群11例中 4 例に， 1 年後の時点て $36.4 \%$ e 抗原が陰性化した。

\section{考案}

これからの成績をみると母親が HBs 抗原陽性例で はステロイド使用後 1 年の時点で23例中 10 例 (43.5\%) とe抗原の陰性化率が低かったが，両親共 HBs 抗原 が陰性あるいは, 父親が HBs 抗原陽性，あるいは肝疾 患で死亡した症例では母親に比べて高頻度にe 抗原の 陰性化が認められた。こうしたことから母親からの HBs 抗原の感染は，感染の機会が多いこと，また，血 液から血液の感染など，感染量の多いことなどが考鼻 られるが, 又幼時期からの母親からの感染による Host 側の反応をむ，この差を生み出すとも考えられる。し かし，一般的な考方方としては，DNA-polymerase が 低い症例に e 抗原の陰性化が認められることやあるい は肝疾患の家族集積のある場合など, Host 側の免度機 構と感染量の問題と両面から，母親からの感染の場合 にe 抗原の陰性化が認められにくいことが示唆され た。

これらのことから，抗核抗体陽性例は，いわゆる自 己免疫疾患之考えられているが，B型慢性肝资におい ても e 抗原陽性例において，頻度が高かったことから， 抗核抗体陽性の $\mathrm{e}$ 抗原慢性肝炎には，いわゆる免疫賦 活療法はむずかしく，むしろステロイド長期間歇療法 の方が適応する可能が考えられた。

索引用語：e 抗原陰性化，家族歴，抗核抗体

\title{
慢性 B 型肝炎に対するインターフェロン療法時の末梢血単核球
}

\section{$2^{\prime}-5^{\prime}$ oligoadenylate synthetase 活性}

\author{
豊田成司菅原俊松嶋喬 \\ （北海道大学第 3 内科）
}

インターフェロン(IFN)の抗ウイルス効果の発現機 序として, IFNによる抗ウイルス蛋白の誘導が指摘さ れており，そのーつとして2'-5' oligoadenylate synthetase (2-5AS) が知られている". 今回, われわ れは, IFN 療法施行時の慢性 B 型肝炎患者の末梢血単 核球 (PBMCs)，および in vitro に IFN 添加培荃後の PBMCs の本醅素活性を測定し, PBMCs・2-5AS 活性 と抗ウイルス効果とを比較検討したので報告する。

$$
\text { 方 法 }
$$

IFN 療法時の 2-5AS 活性湘定は Sokawa らの方
法2゙に準じて行ない，2-5AS 活性は蛋白あたりの 2-5A 生成に要したATP 量として算出し，次式により患者 の2-5AS 活性値とした。

$2-5 \mathrm{AS}$ 活性 = (IFN 投与期間中の 2-5AS 活性の平均 値) -(IFN 投与前の 2-5AS 活性)

また，in vitroには，Ficoll-Conray 法にて分離した PBMCs $4 \times 10^{6}$ 個を $10 \%$ FBS 加 RPMI $16402 \mathrm{~m} l$ k浮 遊させ，IFN を添加培着したのち，栄研 ICL 製 2-5A 合成醭素活性測定用キットを用い，2-5AS 活性を測定 した. 


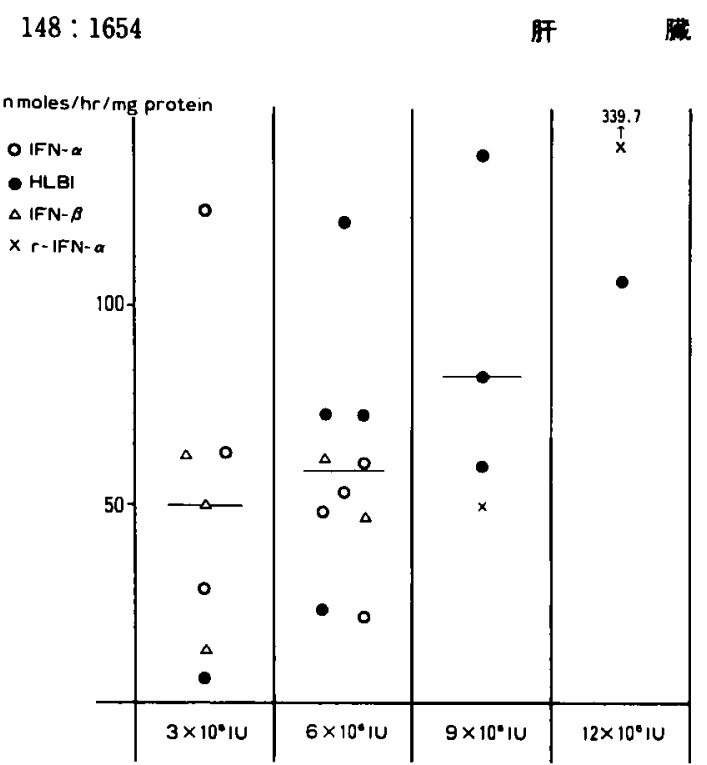

Fig. 1 Correlation IFN doses with 2-5AS activity in PBMCs on chronic hepatitis $B$ during IFN therapy.

\section{成績ならひに考察}

各種 IFN を 4 週間連日投与した慢性 B 型肝炎23例 の患者 PBMCs - 2-5AS 活性は, $3 \times 10^{6} \mathrm{IU} /$ day 投与例 （ 7 例）では $49.7 \pm 39.7 \mathrm{n}$ moles $/ \mathrm{hr} / \mathrm{mg}$ protein（平均

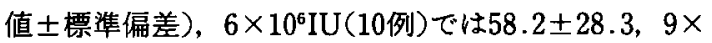
$10^{6} \mathrm{IU}$ ( 4 例) では $82.6 \pm 39.6$ と IFN の増量に伴って 2-5AS 活性す増加する傾向を示したが，同一投与量で る個体差を認めた(Fig. 1). また, ヒト白血球インター $>ェ ロ ン(\mathrm{HuL} \mathrm{IFN}-\alpha) 3 \times 10^{6} \mathrm{IU}, 1$ 回投与時の $2-5 \mathrm{AS}$ 活性の增加を経時的にみると，血中 IFN 活性が peak となる投与後 6 時間頃から上昇し始め 24 時間まで増 加，その後下降した。

PBMCs に HuL IFN- $\alpha$ を添加培養した後の 2-5AS 活性の経時的推移をみた成績では，24時間後には50IU 添加群で $53 \mathrm{f}$ moles $/ \mu \mathrm{g}$ protein, $100 \mathrm{IU}$ で83, $200 \mathrm{IU}$ で114と IFN の添加量の増量にしたがって活性増加を 認めたが，24時間以降は著明な上昇を認めなかった。 また，IFN 添加培養途中で細胞を洗淮して IFNを除 去したのち再培着した成績では， 3 時間 IFN と接触さ せた後，再培盖すると24時間までは経時的に 2-5AS 活 性の増加が観察され，以後下降した。 6 時間接触でも 同様の成績であったが，12時間以降では再培着後は上 昇することなく下降し，IFN の receptor との結合は 極めて速やかに進行し ることが示唆されたが，同時に生成された本酵素の細 胞内でのクリアランスについての検討も必要と考えら

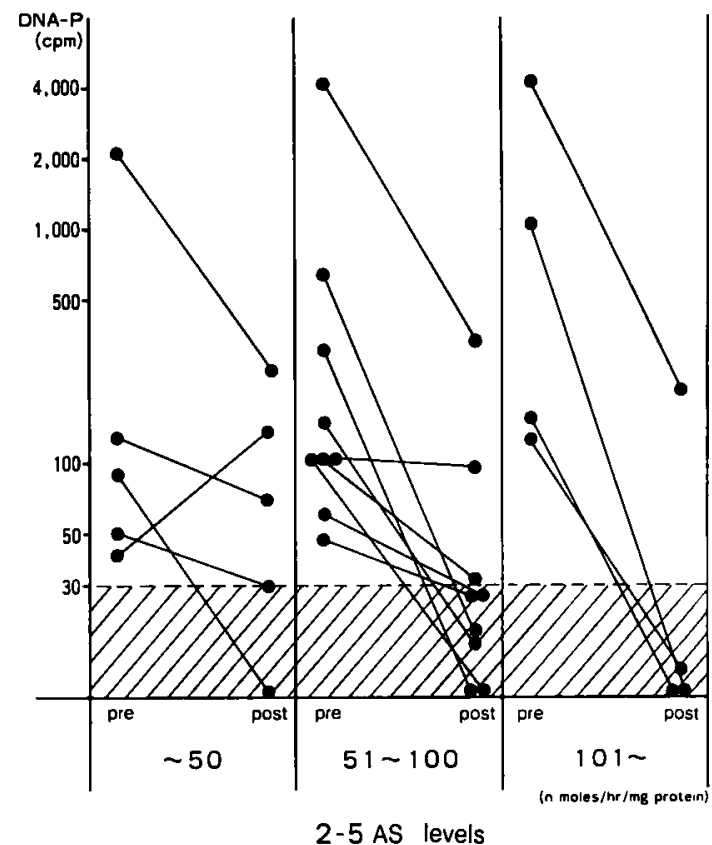

Fig. 2 Reduction of serum DNA.P value after treatment with IFN according to 2-5AS activity in PBMCs.

れた.

IFN $6 \times 10^{6} \mathrm{IU} /$ day 投与例 6 例につき，IFN 療法開 始前, in vitro に PBMCs に IFN 添加培養した後の 2$5 A S$ 活性と IFN 療法施行時の in vivoでの 2-5AS を 比較した成績では，両者は，ほぼ平行関係にあり，IFN 投与前の in vitroでの 2-5AS の反応性をみることに よって in vivo での 2-5AS 活性の上昇をある程度予測 できると考えられた。 IFN 療法施行慢性 B 型肝炎患者 18例の PBMCs・2-5AS 活性を, $50 \mathrm{n} \mathrm{moles} / \mathrm{hr} / \mathrm{mg}$ protein 以下 (低反応群， A 群)，51－100 (中等度反応 群, B 群)，101以上(高反応群， C 群)の 3 群にわけて IFN 投与前後の EIA での $\mathrm{HBe}$ 抗原価を比較すると， $\mathrm{A}$ 群は変化が少なく, B, C 群では $\mathrm{HBe}$ 抗原価の低下 も著しかった。同様に血清 DNA-P 活性はA 群では低 下が軽度であったが，B，C 群では陰性化あるいは著明 な減少を呈した（Fig．2)。これらの成績から，僈性 B 型肝炎に対するIFN 療法に際し末梢血単核球の 2 5AS 活性を測定することは，その抗ウイルス効果をみ る上で有効な手段のひとつとなり得ると考えられ た4).

また, IFN を同一投与量で 4 週間連日投与した場合 の PBMCsの 2-5AS 活性の経過をみた成績では投与 


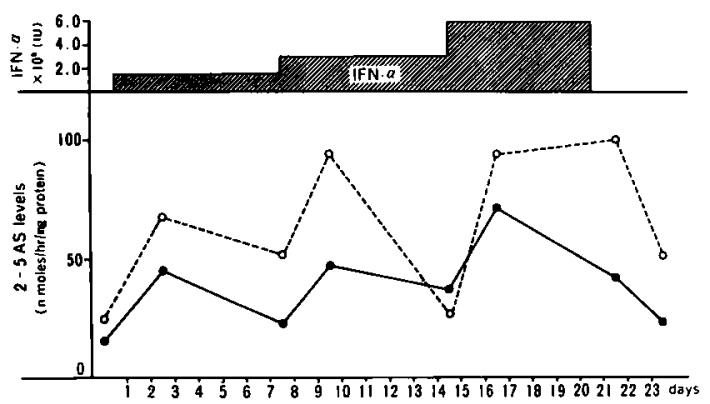

Fig. 3 Time sequential changes of 2-5AS activity in PBMCs of patients with chronic type $B$ hepatitis during interferon treatment.

(- 30 year-old male,

o...... 25 year-old female)

継続にもかかわらず活性低下が観察され, HuL IFN- $\alpha$ を $1.5 \times 10^{6} \mathrm{IU} /$ day, $3 \times 10^{6}, 6 \times 10^{6}$ と漸增して投与した 2 症例の成績でる，投与量の増量にしたがって活性増 加がみられるが，同一投与量を持続すると活性の低下 が認められた (Fig. 3) $)^{5}$. 以上より，IFNを同一量連 日投与ではIFN の抗ウイルス効果が徐々に減弱する 可能性が示唆された。

\section{結語}

慢性 B 型肝炎に対する IFN 㞠法に際し, PBMCs の 2-5AS 活性を湘定して以下の結論を得た。

1) PBMCs・2-5AS 活性は投与 IFN の増量にした がって上昇したが，個体差も認められた。

2) PBMCs・2-5AS 活性上昇の程度と血清 $\mathrm{HBe}$ 抗 原価および DNA-P活性低下とはょく相関し,
$\mathrm{PBMCs}$ ・2-5AS 活性の測定はIFN の抗ウイルス効果 の判定に良い指標となると考えられた。

3）IFN の継続投与によりPBMCs・2-5AS 活性は低 下した。したがってより合理的な IFN 療法を行なう には間歇投与，漸増投与など投与方法の工夫が必要之 考えられた。

索引用語：インターフェロン， $2^{\prime}-5^{\prime}$ oligoadenylate synthetase, 抗ウイルス効果

\section{文献}

1) Schattner A, Merlin G, Wallach D, et al: Monitering of interferon therapy by assay of $\left(2^{\prime}-5^{\prime}\right)$ oligoisoadenylate synthetase in human peripheral white blood cells. J Interferon Res $1: 587-593,1981$

2) Sokawa $Y$, Ando $T$, Ishihara $Y$ : Induction of 2,5-oligoadenylate synthetase and interferon in mouse trigeminal ganglia infected with herpes simplex virus. Infect Immun $28: 719-723,1980$

3）米原伸：インターフェロン受容体. 「インター フェロン研究の進歩!川出由己, 桑田次男, 小林茂 保編, 共立出版, 東京, 1981, p329-335

4) Sugawara T, Matsushima T, Toyota J, et al: Activities of $2^{\prime} \cdot 5^{\prime}$ oligoadenylate synthetase in peripheral blood mononuclear cells of patients with viral hepatitis, and chronic type $B$ hepatitis during interferon therapy. Jap J Med $25: 144-148,1986$

5) Matsushima T, Sugawara T, Toyota J, et al: $\left(2^{\prime} \cdot 5^{\prime}\right)$ Oligoadenylate synthetase levels in peripheral blood mononuclear cells of patients with viral hepatitis. Jap J Med $24: 355,1985$

\title{
B 型慢性肝炎に対する抗ウイルス療法 一Interferon 単独治療による長期予後を中心に一
}

\author{
袖山 健 清沢 研道依田 英俊 \\ （信州大学第二内科）
}

近年 B 型慢性肝资に対する抗ウイルス療法が試み られ，投与中および投与後 6 カ月間程度の経過観察に よる成績が報告されている1て4.

しかしこれら治療法のB型慢性肝资の長期予後に およほす効果には未だ不明な点が多く5)，効果判定の 時期についても一定の見解は得られていない.そこで, 抗ウイルス療法, 特に IFN 比較的大量投与 1 クール施
行後特殊治療を施行せず䅅過観察中の B 型慢性肝炎 例について，比較的長期間の予後，有効例の特徵，効 果判定の時期を検討した。

対象および方法

対象は, Interferon (IFN) 1 クール（4週間) 投与 後 1 年間以上特殊治療を施行せず経過観察しえた $\mathrm{HBeAg}$ 陽性 B 型慢性肝炎26例（男：女 $=23 ： 3$ ）で 
ある。治㞠前肝組織像は慢性肝炎非活動性 (CIH) 6 例, 慢性肝炎活動性 (CAH) 12例，小葉改筑傾向を伴与慢

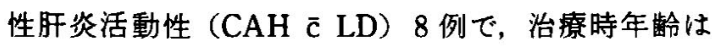
24 47歳 (平均 36.4 歳), 治療後の経過観察期間は 12〜66力月間, 平均30.0力月間である. IFN 投与総量 は, IFN- $\alpha,-\beta$, HLBI で1.5 2 億単位, recombinant $\alpha$ で約 5 億単位である. 対照例として組織学的診断後 特殊治療を施行せず 1 年間以上経過観察しえた成人の HBeAg 陽性 B 型慢性肝炎60例（男：女 $=52 ： 8$ ）を 選択した，対照例の観察開始時肝組織像は CIH 14例, $\mathrm{CAH} 26$ 例, CAH c $\mathrm{LD} 20$ 例で，年齢は23 51藏（平 均 34.7 藏), 経過観察期間は18 48力月間, 平均 34.0 力 月間である. 両群の血中 HBV marker, 肝組織像等の 推移を比較検討した，また，対象例では血清中 HBV DNA, 肝組織中 HBcAg の推移も検討し，さらに AraA 投与例10例, Steroid Rebound (SR) 治療例 6 例の $\mathrm{HBeAg}$ の推移についても検討した.

\section{成 績}

1. IFN 治療終了後 1 年, 2 年の時点の $\mathrm{HBeAg}$ 消 失は, 各々 $11 / 26(42.3 \%), 7 / 16(43.7 \%)$, Ara-A 10 例では6/10 (60\%), 3/9 (33.3\%), SR 5 例では2/ 5 (40\%)，3/4 (75\%) であった。これに対して無治療 の対照75例では各々 $4 / 75$ (5.3\%)，9/64 (14.1\%) で あり, 治療例は対照例に比し HBeAg 消失が高率で, 特に IFN 投与例では有意であった。

2. IFN 治療例の $\mathrm{HBeAg}$ の推移，および $\mathrm{HBeAg}$ 消失率を組織像別に Fig. 1 に示した。一時的なものも 含む $\mathrm{HBeAg}$ の消失は， $\mathrm{HBeAg}$ に変化のみられた 17 例中14例で IFN 投与終了後 1 年以内の時点であった。 14例中 8 例はその後持続的に HBeAg 陰性となり GPT 值む正常化し， ちち CAH ないし CIH の 3 例は anti-HBe 一 seroconversion した，また他の 3 例中 2 例も投与終了後 1.5 年以内に $\mathrm{HBeAg}$ の持続的消失を 認め GPT も正常化した。 しかし， 1 年以内に $\mathrm{HBeAg}$ 陰性化のみられた14例中 6 例ではその後 HBeAg の再 出現を認め，その時期は 5 例で治療後14カ月以内で あった。これら6 例全例で GPT 値の異常が持続した. $\mathrm{HBeAg}$ 消失率を組織像別にみると， $\mathrm{CAH} \overline{\mathrm{c}} \mathrm{LD}$ では 対照例に比し有意に高率ではあるが，一方再出現す高 率であり, HBeAg の持続陰性化率は $\mathrm{CAH}$ と注ぼ同

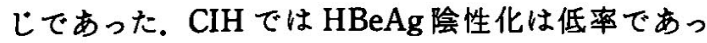
た.

3. IFN 治療例26例中11例に投与終了後 1 ～ 2 年の 時点 (Fig. 1 の矢印)で追跡肝生検を施行した. Fig. 2

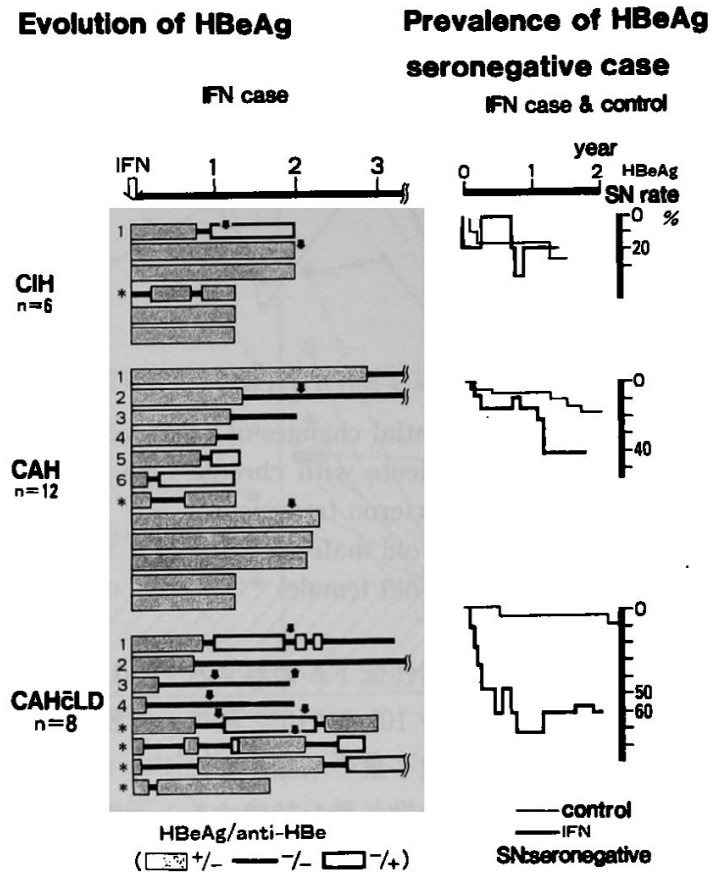

Fig. 1 Evolution of $\mathrm{HBeAg}$ and prevalence of $\mathrm{HBeAg}$ seronegative cases in 26 cases treated with interferon with regards to liver histology.

に示すごとく，対照例の追跡肝生検では観察開始時よ り 2 年以降高率に活動性の肝硬変 (active LC) への進 展がられたのに対し，IFN 治療例で active LCへの 移行は 1 例のみであり，この症例も anti-HBe 陽性期 に CAH c LDへと軽快した. $\mathrm{HBeAg}$ の消失がみられ た CAH c LD 5 例を含む 7 例では，炎症所見の著明な 改善と肝組織内 $\mathrm{HBcAg}$ 消失を認めた。

4. IFN 投与終了後 1 年前後の時点までに $\mathrm{HBeAg}$ が消失し以後持続的に陰性となり，かつGPT 値も正 常化した10例と，IFN 投与後も HBeAg が持続陽性で あった 9 例の臨床事項の比較を Table 1 に示した. 前 者10例では，治療前肝組織像は活動性が強く，IFN 投 与終了後 transaminase の高値を示し, 治療前 GPT 值 が高く DNA-p 値が低い傾向がみられた。また。これら 10例ではIFN 投与後半年，1 年の時点で各々 8,9 例 が HBV-DNA 陰性であった. HBeAg 持続例では治療 前 GPT は低値で治㞠後も軽度異常値で推移した。

\section{結論}

B 型慢性肝炎に対する抗ウイルス療法は, 治療後 1 年の時点の $\mathrm{HBeAg}$ 消失率を増加させており，有効と 考えられた。 IFN 単独 1 クール投与例の予後をみる 
control

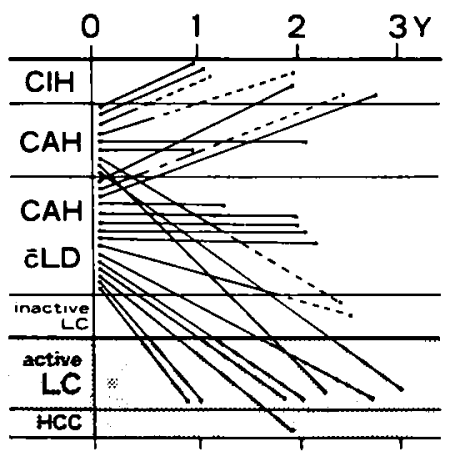

CAHC̄LDractive LC 6/15
IFN treated case

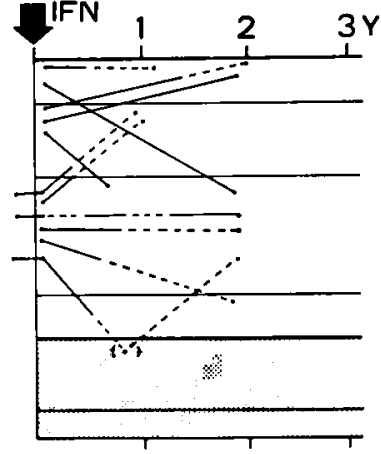

$1 / 6 \quad 0 / 6$

intrahpatic $\mathrm{HBCAg}(+)$ ve $8 / 9-1 / 9$

$$
\begin{aligned}
& -\operatorname{HBeAg}(+) \\
& \ldots . . \operatorname{HBeAg}(-)
\end{aligned}
$$

Fig. 2 Histological outcomes in 10 cases treated with interferon and in 24 control cases.

Table 1 Clinical, histological and virological aspects in patients with chronic hepatitis type B before and after interferon therapy.

- Before therapy -

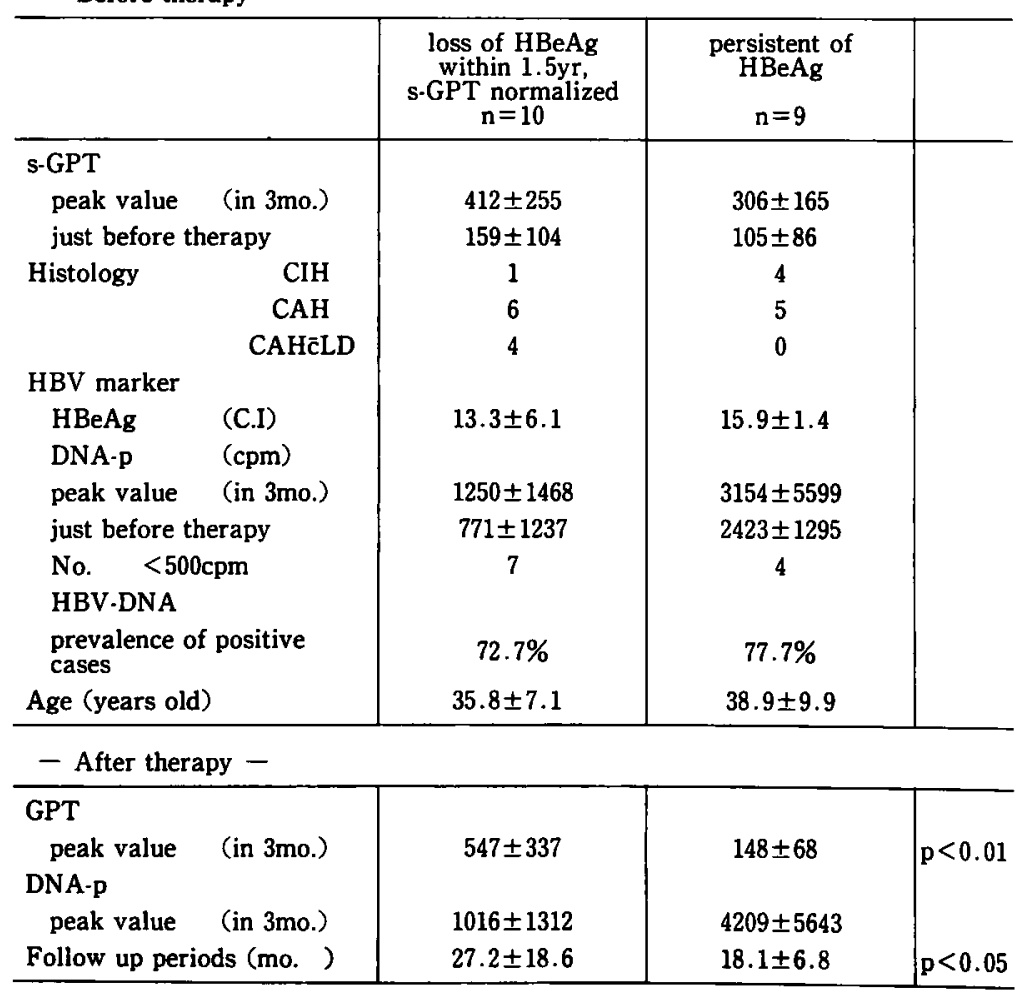


と, CAH ないし CAH c LD 20例中 8 例で治療後 1 年 前後の時点までに HBeAg が陰性化，以後同状態が持 続し GPT 正常化した。 しかし，CAH c LD 3 例を 含む 5 例では治療後 $\mathrm{HBeAg}$ の陰性化を認めたもの の, 治療後 1 年以内に再出現, 以後持続陽性ないし出 没し著明な GPT の異常値が持続した。したがってそ の効果判定は治療後 1 - 1.5年が適当で, この時点で無 効例に対しては再治療をすべきと考えられた，有効例 は HBeAg 持続例に比し治療前 DNA-pが低值で GPT が高値の傾向があり，治療後 GPT の高値を示し た. 組織学的予後を対照例と比較した結果, 活動性肝 硬变への移行が低率で，有効例では著明な炎症所見の 改善を認めた。

索引用語：B型慢性肝炎の治療, Interferon, 抗ウイ ルス療法

\section{文献}

1) Greenberg HB, Pollard RB, Merigan TC et al : Effect of human leukocyte interferon on he- patitis $\mathrm{B}$ virus infection in patients with chronic active hepatitis. N Engl J Med 295 : 517-552, 1976

2) Weimar W, Ten Kate FJP, Masurel N, et al: Double-blind study of leukocyte interferon administration in chronic $\mathrm{HBsAg}$-positive hepatitis. Lancet $2: 336-338,1980$

3) Scullard GH, Greenberg HB, Merigan TC, et al : Antiviral treatment of chronic hepatitis $B$ virus infection. Improvement in liver disease with interferon and adenine arabinoside. $\mathrm{He}$ patology 1:228-232, 1981

4）鈴木 宏，市田文弘，古田精市，他：HBV関連 DNA-polymerase 陽性慢性活動性肝炎に対する ヒトインターフェロンー $\alpha$ およびー $\beta$ 療法およびそ の比較。肝䁍 $24: 955-968,1983$

5）古田精市, 袖山 煡, 清沢研道, 他：B 型慢性肝炎 の薬物療法による長期予後一単独療法一IFN.「第 14回犬山シンポジゥム記録. B 型慢性肝炎の診断, 治療, 予防」中外医学社, 東京, 1986, p102-110

\title{
肝内ウイルス増殖から見た抗ウイルス療法
}

\author{
小俣 政男 横須賀 収 広田勝太郎 \\ （千葉大学第一内科）
}

\section{はじめに}

Hepadna ウイルス增殖系は近年明確にされ，肝組織 において各々の増殖過程の検索が可能となった ウイルス剤(インターフェロン-IF, 或いは Adenine Arabinoside-Ara-A)を投与する事により，血中のウィ ルス DNA 或いは DNA-ポリメラーゼ (DNA-p) は減 少し，ある場合には著効を呈し，又ある場合には無効 である．我々はこれら薬珮がいかに肝内ウイルス増殖 系を抑制，またなぜ無効となる場合があるのかの点に 興味を持ち検討を加えた。

\section{対象及び方法}

インターフェロンはロッンェ社の recombinant $\alpha$ 型を20名に投与(3,600万/日 $\times 28$ 日から 1 億単位/日 $\times$ 28日）した。ここれ投与例での薬理学的，抗ウイルス 効果はすでにその詳細を報告しだ3。これらの症例に 怙いて前後肝生検を15名の症例につき行い，肝内のウ イルス増殖動態を検索した. Ara-A は hepadna ウイ ルスの一種である duck hepatitis B virus (DHBV)
感染 (実験室内) アヒルに $20 \mathrm{mg} / \mathrm{kg}$ から $80 \mathrm{mg} / \mathrm{kg}$ を投 与する事により，肝楔状生検を取り（前, 投与直後, 及び 4 週後) 肝内ウイルス增殖動態を調べた。肝内ウ イルス増殖動態の検索法はウイルス DNA をプローブ とした Southern blot hybridization 法により行い，そ の Southern blot 像を densitogram を用い数量的に表 示した。 また肝内におけるウイルス二重鎖 DNAのそ れぞれを恰索する為にプラス鎖 (或いは短鎖)DNA と 結合するプローブ（RNAプロープ）を SP6システム を用い作製した。

HBV DNA を pSP 64のプラスミッドに組み込む。 この際組み込まれた方向によりつくられてくる RNA (これをブローブに用いる）が極性を有する。この RNA プロープを用いる事により，プラス鎖 DNA が 特異的に検出される（Fig. 1a）。

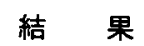

インターフェロン投与例では投与後肝生検で肝内ウ イルス DNA が検出されない症例では血中でもウイル 


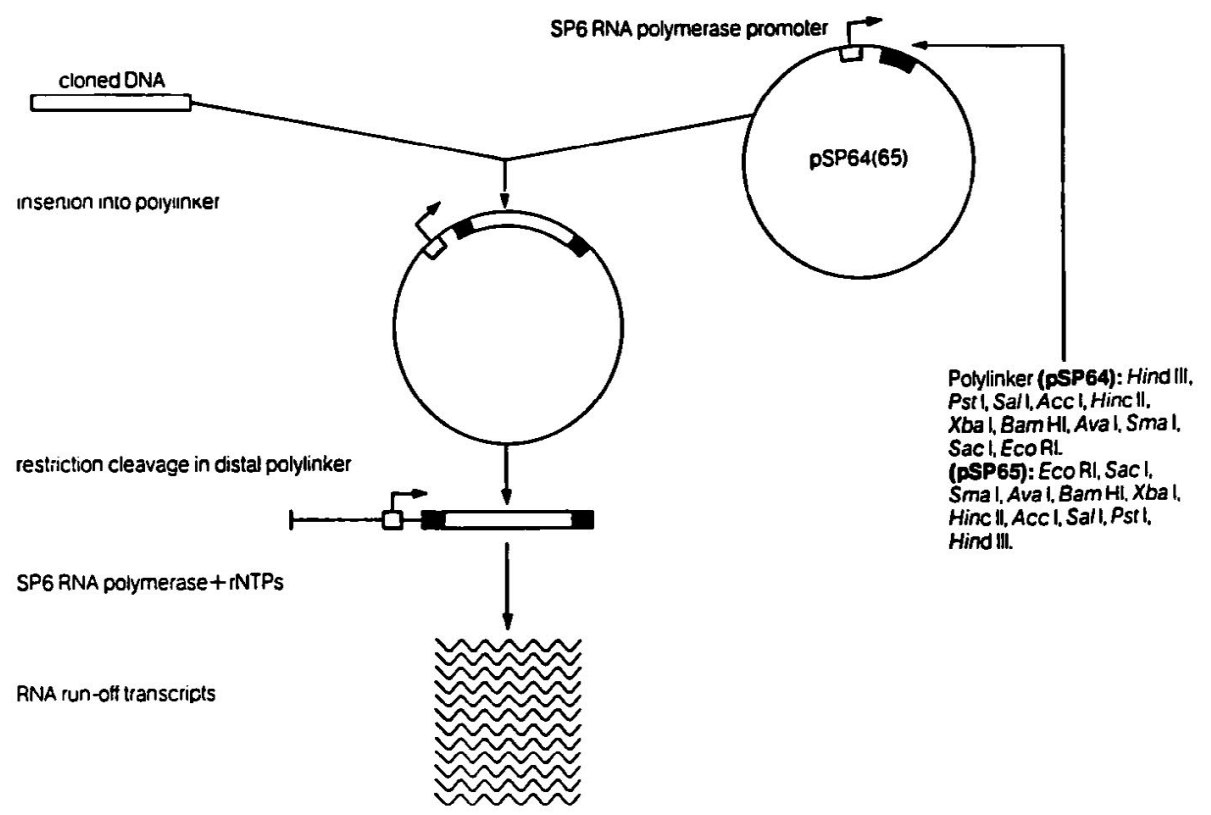

Fig. 1a The schematic presentation of plasmid (SP6) to make strand specific RNA probe. Cloned DHBV DNA was inserted into SP6 plasmid which has polylinker and promoter.

After cleaving the plasmid in distal polylinker, strand specific RNA probe could be synthesized by RNA polymerase. Strand specificity could be decided by the orientation of inserted DNA.

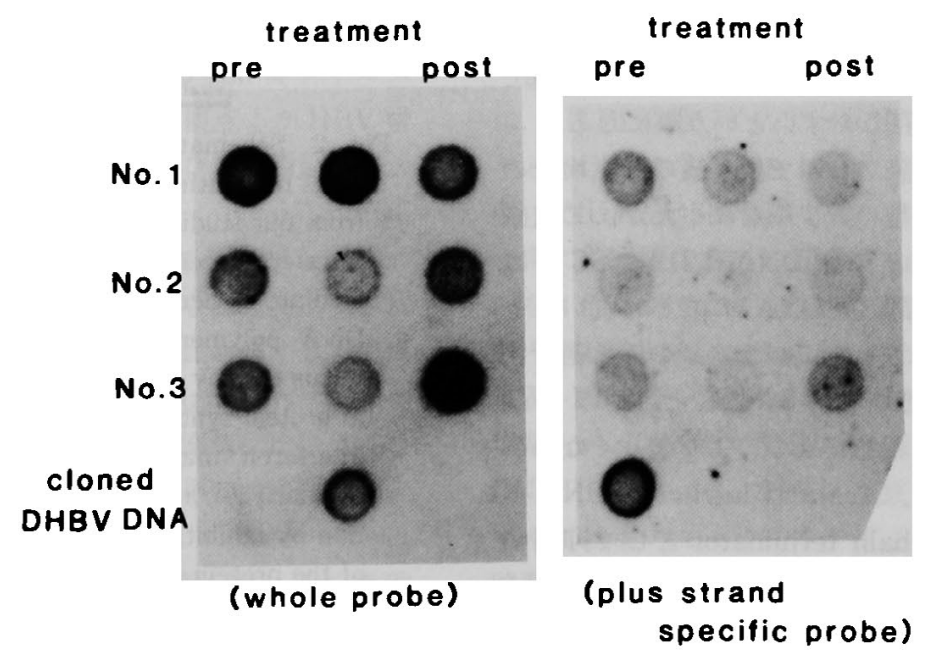

Fig. 1b The changes of hepatic viral DNA in three ducks (\#1,2, \& 3). The DNA was studied in just before the treatment ("pre"), at the end of treatment, and 4 weeks after Ara-A treatment ("post") $(80 \mathrm{mg} / \mathrm{kg}$ ).

More marked reduction of viral DNA by the treatment was noted with plus strand specific RNA probe than with two strands DNA probe. 
Table 1 Correlation of intrahepatic HBV DNA and serum HBV DNA in 15 interferon treated patients.

\begin{tabular}{l|c|c|c|c|c|c|c|c}
\hline \multirow{2}{*}{ Serum HBV DNA } & \multirow{2}{*}{$\mathrm{n}$} & \multicolumn{3}{|c|}{ Hepatic HBV DNA } & \multicolumn{4}{c}{ Interferon Doses (megaunits/d) } \\
\cline { 3 - 9 } & & Negative & Decreased & Unchanged & 36 & 50 & 72 & 100 \\
\hline Persistently Negative & 5 & 4 & 1 & 0 & 2 & 0 & 1 & 2 \\
Transiently Negative & 5 & 0 & 2 & 3 & 1 & 3 & 1 & 0 \\
Persistently Positive & 5 & 0 & 2 & 3 & 2 & 0 & 2 & 1 \\
\hline
\end{tabular}

ス持続消失例が多く見られた (Table 1)。一方，逆に 肝内ウイルス DNA が残存する例では血中においても ウイルス DNAの一時的消失，或いは減少のみで消失 しない例が多く見られた (Table 1)。ざらに，そのウ イルス残存形態を調べると Supercoiled form (SC) 型 が残存しゃすかっだ). Supercoiled 型 DNA はウイル スが肝内に浸入直後に形成されら方，ウイルス転写の最 初の鋳型となると考えられている。このSC 型は通常 血中ウイルス DNAに由来すると考えられる。した がってインターフェロンは一部の例では肝内のウイル ス DNAをよく抑制するが，一方，無効例で残存しやす いのは最初の転写鋳型といら事が判明した。.Fig. 2 に mRNA を含むウイルス增殖系を示してある. イン ターフェロンは mRNAを变性させるという in vitro 実験データーがあるが, in vivoのウイルス核酸の側か ら見ても，やはりインターフェロンはウイルス mRNA を変性させそれ以後のウイルス増殖を抑制さ せるといら事が判明した (Fig. 2). したがって鋳型で ある SC 型 DNA は残存しやすいという事になる。

Ara-A は DHBV 感染アヒルで投与後の肝生検での 各ウイルス DNA 増殖型の減少率を調べたが，二重鎖 DNAの減少率は $39 \%$ ，単鎖 DNAは21\%, SC 型は $1 \%$ 乙重鎖（或いは成熟型 DNA）になるに従い，そ の堿少率は増加した。さらに，プラス鎖のみと結合す るRNA ブローブを用いて検討すると、プラス鎖 DNA の減少は Ara-A 治療により，より著しくなる事 が確認された (Fig. 3). Ara-A は in vitroでDNA ポ リメラーゼの活性を chain terminator として抑制す るといわれている. 従って Hepadna ウイルス DNA の肝内における二重鎖化を㧕制すると考えられる。 たこの hepadna ウイルス増殖の特徵である RNAか ら DNA への逆転写の過程を司る逆転写䤃素活性も抑 制すると考えられる. 単鎖 DNAの減少が，二重鎖 DNA ぽではないにしてるある程度見られた事は逆 転写の過程む抑制されると考えられた。

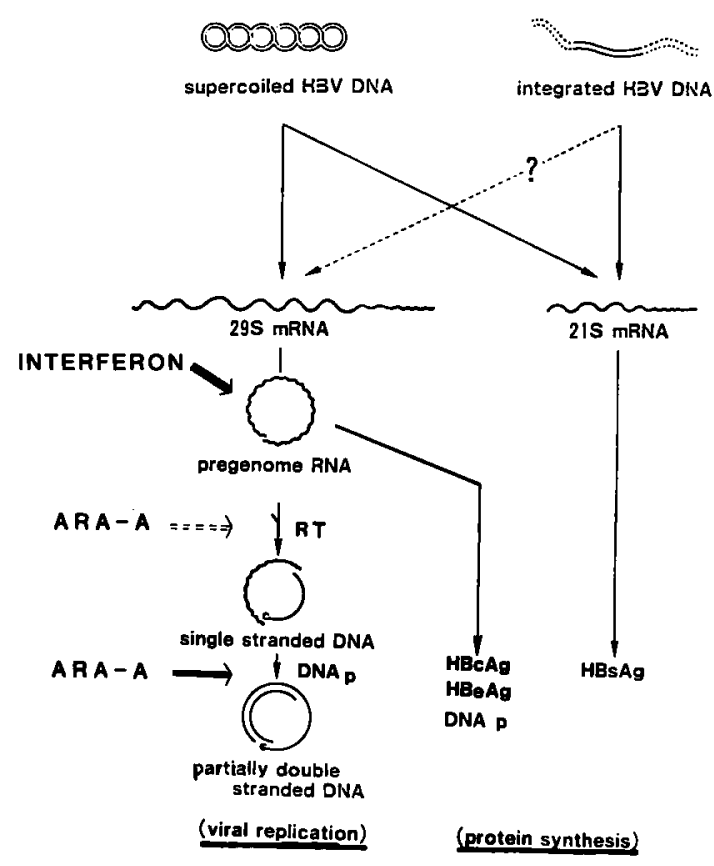

Fig. 2 Schematic presentation of intrahepatic virus replication and protein syntthesis deducted from our studies and others.

Interferon seems act on mRNA (or RNA intermediate), whereas Are-A seems primarily act on DNA polymerase function. Since 295 mRNA seems to play a key role in viral replication and in protein synthesis, degradation of the RNA by interferon may interfere the virus synthesis. Similarly, Ara-A may interfere the viral replication by inhibition of DNA polymerase, but some of the protein synthesis may continue because of intact mRNA.

The supercoiled form of viral DNA seems least affected by the treatment.

\section{まとめ}

抗ウイルス剤の肝でのウイルス抑制機序の検索を行 い, IF は mRNA の変性を介し，また Ara-A は DNA ポリメラーゼの活性抑制を介して, IF は単鎖 DNA 合 
成以降を，又Ara-A は DNA の二重鎖化を抑止すると 考えられる。しかしながら，転写鋳型である SC 型 DNA は残存しやすい。このSC型 DNA は血中 Virion 由来と考えられており，抗ウイルス剂が十分効果 を発揮できないのは，SC 型 DNA の减少が十分でな く，抗ウイルス剤中止後これを火種として再然すると 考えられる。

よりよき治療には，a）ウイルスの浸入防止，b）肝 内での増殖抑制，c）抗原を発現する細胞破壊の多段 階的なるのが必要と考えられる。

索引用語：インターフェロン, Ara-A, Virus replication

\section{文献}

1) Omata M, Yokosuka O, Imazeki $F$, et al: Correlation of hepatitis B virus DNA and antigens in the liver : a study in chronic liver disease. Gastroenterology 1986 (in press)
2) Yokosuka O, Omata $M$, Imazeki $F$, et al: Active and inactive replication of hepatitis $B$ virus DNA in chronic liver disease. Gastroenterology $85: 610-616,1985$

3) Omata M, Imazeki F, Yokosuka $O$, et al: Recombinant leucocyte $A$ interferon treatment in patients with chronic hepatitis $B$ virus infection. Pharmakokinetics, tolerance, and biologic effect. Gastroenterology 88 : 870-880, 1985

4) Yokosuka O, Omata $M$, Imazeki $F$, et al : Changes of HBV DNA in liver and serum caused by recombinant leucocyte interferon treatment : analysis of intrahepatic replicative HBV DNA. Hepatology 5 : 728-734, 1985

5) Tagawa $M$, Omata $M$, Okuda $K$ : Appearance of viral RNA transcripts in the early stage of duck hepatitis B virus infection. Virology 152 : 477-482, 1986

\title{
B 型慢性肝炎における Ara-A・Interferon 併用療法の検討
}

\author{
川口 秀輝 上村 朝輝市田 文弘 \\ (新潟大学第三内科)
}

はじめに

$\mathrm{B}$ 型慢性肝炎の増悪, 進展には B 型肝炎ウイルス (HBV)の増殖が必原であり，かかる観点より HBV 排 除を目的とした抗ウイルス療法および免疫調節療法が 試みられている.

Greenberg ら"は，本疾患に対して最初に Interferon（IFN）単独療法を施行しその後各施設で追試され ているが，その成績は自然経過例に比し必ずしも满足 すべきすとはいえない，また, Merigan ら 2.31は, AraA・IFN の併用療法を試み IFN 単独療法に比し良好な 成績をえているがその相乗する副作用の故に報告は少 ない。

今回，著者らは B 型慢性肝炎患者に対 L IFN 単独 療法, Ara-A - IFN 併用療法を施行し両療法の病態に 及ぽす効果を主として HBV 堌殖と抗ウイルス作動機 構との関連性の面から検討した。

\section{对象およU゙方法}

対象は, IFN 単独療法群 (I 群) 17例, Ara-A·IFN 併用㞠法群 (C 群) 8 例で，年龄，性差，組織型， $\mathrm{HBe}$ 抗原価，DNAP 活性，トラレスアミナーゼ值などの背
景因子には両群間で差を認めなかった。

投与方法はI 群では IFN- $\beta$ 総量 $102 \times 10^{6} \mathrm{IU}$ を 9 例 に, HLBI 粉量 $168 \sim 252 \times 10^{6} \mathrm{IU}$ を 8 例に 28 日連日投 与し, C 群ではAra-A $10 \mathrm{mg} / \mathrm{kg} /$ 日を 1 週間, IFN- $\beta$ $6 \times 10^{6} \mathrm{IU} /$ 日を 3 週間を 1 クールとして計 2 クールを 4 例に，同様の方法で IFN- $\beta$ を $3 \times 10^{6} \mathrm{IU} /$ 日としたも のを 4 例にいずれも連続的に投与した。 9 例において 肝内 HBV.DNA を Southern blot 法にて検索し血中 HBV-DNA との signal の一致を確認し，血中 $\mathrm{HBV}$ 増殖マーカーとして HBV-DNA (dot hybridization), DNAP (kaplan 5), $\mathrm{HBe}$ 抗原・抗体系 (EIA), 抗兵 イルス状態のモニターリングとして末梢血単核球中 $2^{\prime}, 5^{\prime}$ oligoadenylate synthetase $(2,5$ AS) 活性を Sokawa 54の方法, 肝内 $\mathrm{HBc}$ 抗原は酵素抗体間接法 にて検索した。

\section{成績および考寨}

血中 DNAP 活性および HBV-DNA の陰性化率は, I 群， C 群で投与終了時各々16例中 5 例 $(31.2 \%), 8$ 例中 5 例 $(62.5 \%) ， 6$ 力月で16例中 2 例 $(12.5 \%)$, 7 例中 3 例（42.9\%）でありI群に比しＣ群で高率に 


\section{Disappearance rate of $\mathrm{HBeAg}(\%)$}

\begin{tabular}{|c|c|c|c|}
\hline $\begin{array}{l}\text { IFN } \\
\text { alone }\end{array}$ & $\begin{array}{l}1 / 17 \\
(5.9)\end{array}$ & $\begin{array}{l}1 / 15 \\
(6.7)\end{array}$ & $\begin{array}{c}2 / 15 \\
(13.3)\end{array}$ \\
\hline $\begin{array}{l}\text { Comb. } \\
3 \times 10^{5} \mathrm{U} / \mathrm{d}\end{array}$ & $\begin{array}{l}0 / 4 \\
(0)\end{array}$ & $\begin{array}{l}0 / 4 \\
(0)\end{array}$ & $\begin{array}{l}0 / 4 \\
(0)\end{array}$ \\
\hline $\begin{array}{l}\text { Comb. } \\
6 \times 10 \mathrm{~b} / \mathrm{d}\end{array}$ & $\begin{array}{l}1 / 4 \\
(25)\end{array}$ & $\begin{array}{c}2 / 3 \\
(66.7)\end{array}$ & $\begin{array}{c}2 / 3 \\
(66.7)\end{array}$ \\
\hline
\end{tabular}

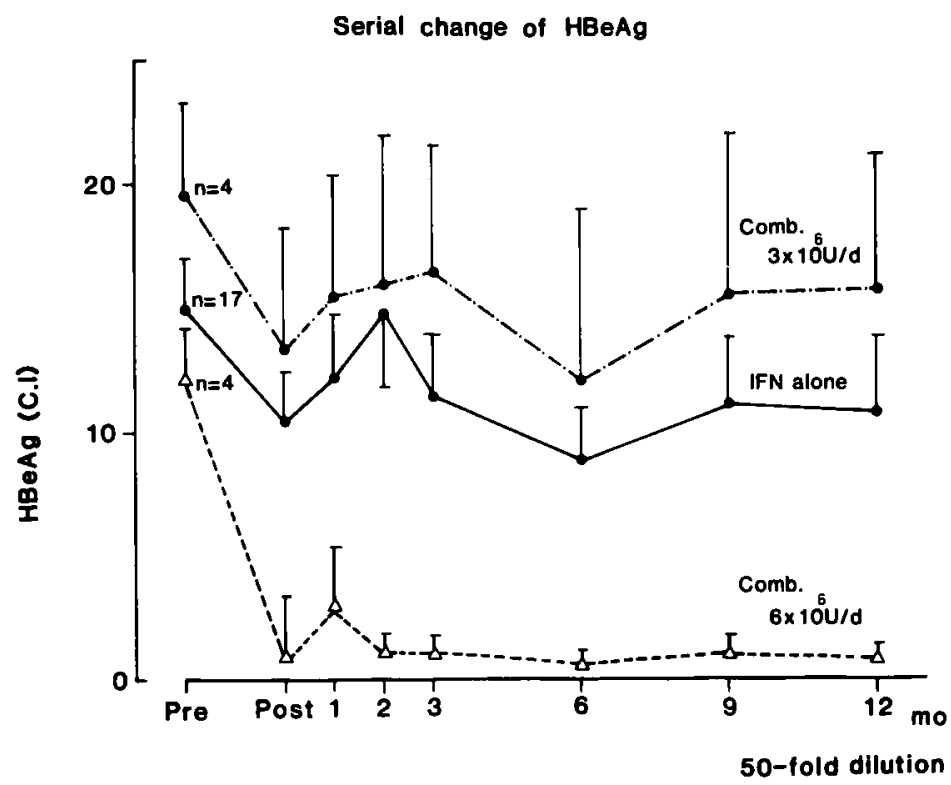

Fig. 1 Disappearance rate of $\mathrm{HBeAg}$ and serial change of $\mathrm{HBeAg}$ in 25 patients treated with interferon alone or combination therapy.

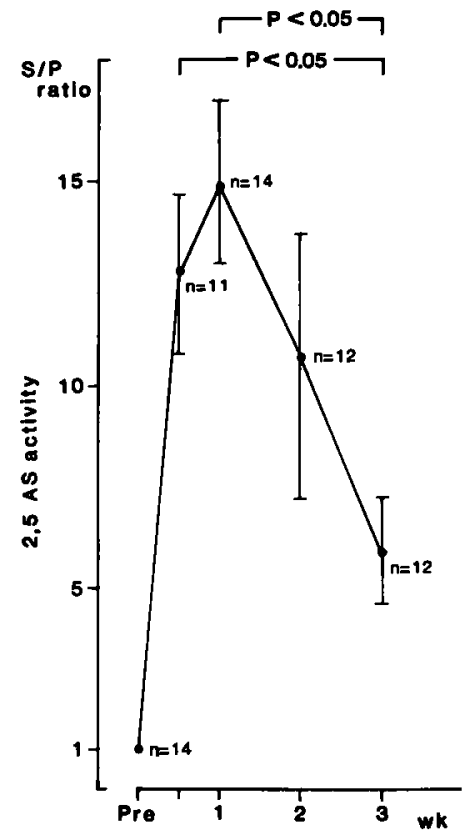

Fig. 2 Change of 2, 5 AS activity during interferon administration.
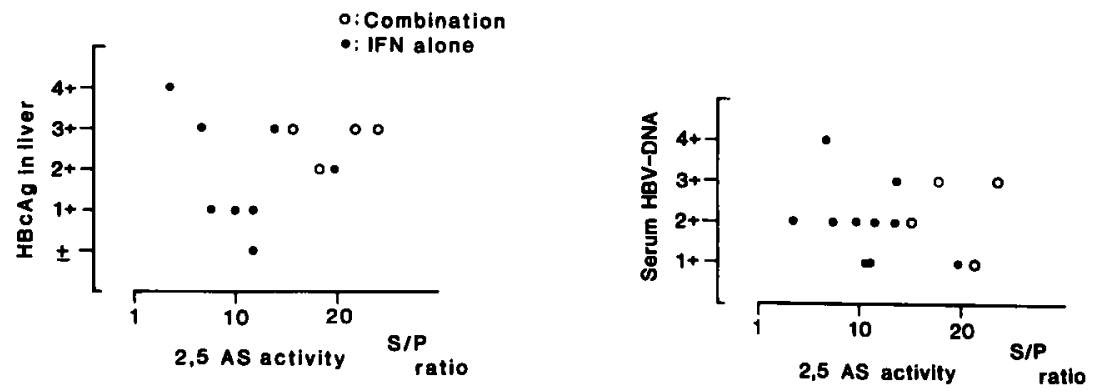

Fig. 3 Correlation between 2, 5 AS activity and $\mathrm{HBcAg}$ in liver or serum HBV-DNA.

認めた. $\mathrm{HBe}$ 抗原の消失率ではI 群で終了 6 カ月, 12 カ月で各々 15 例中 1 例 $(6.7 \%), 15$ 例中 2 例 (13.3\%) であるのに対し，C群の high dose 投与例において同 時期で 3 例中 2 例 $(66.7 \%)$ とI 群に比し高率であっ
た. 50倍希釈血清における $\mathrm{HBe}$ 抗原価 (CI) の動態に おいてもI群では 6 カ月以降再上昇を認めたのに対し C 群の high dose 投与例では長期にわたる本抗原価の 低下を認めた (Fig. 1). 
次にIFN 連日投与時の抗ウイルス状態を反映する 2,5 AS 活性の経時的变動を愉討すると, 本䣼素活性は IFN 投与早期に上昇し投与 1 週で maximum level に 達するも以後低下するパターンを多く認めた。 また， 投与 3 週目では， 3 日目， 1 週目に比し本活性は有意 の低下を示した (Fig. 2)。この成樍は，連日投与にも 拘らす投与後半には抗ウイルス機構の作動は不充分々 なっていることを示唆させ，IFN の中止あるいは継続 などの投与方法の決定に本酵素活性の経時的な測定は 有用な指標となりらるものと考えられた。

$\mathrm{HBV}$ 增殖と IFN 投与時の 2, $5 \mathrm{AS}$ 活性の誘導との 関連性を検討する目的で，治療前の肝組織内 $\mathrm{HBc}$ 抗 原量および血中 HBV-DNA 量とIFN 投与 1 週目に おける2, 5 AS 活性比をブロットするとI群において は $\mathrm{HBc}$ 抗原量あるいは血中 HBV-DNA 量が多い例 では本醭素活性の誘導が不良である例を多く認めたの に対し，C群ではI群に比し本活性が高值を示しまた 両マーカー量が多い例でるその誘導は良好であった (Fig. 3). IFN 単独療法施行例における有效例，無効 例の検討より，DNAP 活性および HBe 抗原価の低い 例に有効例が多く認められるといら事実は，2,5 AS 活 性の反応性とい5観点からも説明し5るものと思われ る.これらに対して併用群では，IFNに先行する AraA 投与による $\mathrm{HBV}$ 増殖の抑制効果がより有効な IFN の抗ウイルス機構の作動を発現させらるものと 考えられた。

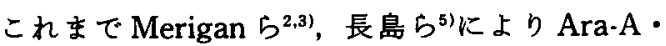
IFN の併用療法の成績が報告されているが，両薬剤の 投与方法，投与量，対象症例の選択などに関しては一 定の見解はえられていない，今回，著者らは本併用療
法の有効性およびその理論的背景を明らかにしたが， 今後更に症例を増して検討する必要があると考える．

\section{結論}

1. Ara-A -IFN 併用㞠法群の high dose 投与例に拉 いて IFN 単独療法に比し，血中 HBV 增殖マーカーの 消失を高率に認めた。

2. 肝内 $\mathrm{HBC}$ 抗原量が多い例でも, 併用療法群では IFN 投与時の2, 5 AS の誘導が良好であった。

3. 2,5 AS の経時的測定は，IFN 投与方法の決定に 有用な指標となりらるすのと考えられた。

臬引用語: HBV マーカー, 2', $5^{\prime}$ oligoadenylate synthetase, 肝内 $\mathrm{HBc}$ 抗原

\section{参考文献}

1) Greenberg HB, Pollard RB, Lutwick LI, et al: Effect of human leucocyte interferon on hepatitis $B$ virus infection in patients with chronic active hepatitis. N Eng J Med 295: 517-522, 1976

2) Scullard GH, Pollard RB, Smith JL, et al: Antiviral treatment of chronic hepatitis $B$ virus infection. I. Changes in viral markas with interferon combined adenine arabinoside. $J$ Infect Dis 143 : 772-783, 1981

3) Smith CI, Kitchen LW, Scullard GH, et al : Vidarabine monophosphate and human leucocyte iuterferon in chronic hepatitis $B$ infection. JAMA $247: 2261-2265,1982$

4) Shimizu N, Sokawa $Y: 2^{\prime}, 5^{\prime}$-oligoadenylate synthetase activity in lymphocytes from normal mouse. J Biol Chem 254 : 12034-12037, 1979

5）長島秀夫, 有馬嘎勝, 羽田 元, 他：B 型慢性肝资 に対するIFN $\alpha$ (静注)と Ara-A の併用療法. “犬 山シンボシゥム 14 "194-200, 1985

\section{司会者のまとめ}

\section{瀧野 辰郎 古田 精市}

B 型慢性肝炎の病因は HBV の持続感染による肝臓 の慢性炎症であることが解明され，HBV 感染撲堿を 指向する治㞠法として IFN や Ara-A 等の抗ウイルス 剤, 生体の感染防㲛機構を増幅させる immunomodulatorが試みられている.本パネルではこれら治療法に おけるウイルス学的, 生化学的, 免疫学的な病態の面 よりみた効果の評価とその限界を討議し，さらにその
臨床成績をふまえて今後検討すべき諸問題についての 討議を行った. IFN 単独投与では肝内の HBV を完全 に除去することは困難であり，他の抗ウイルス剂との 併用, 開発が望まれるが，自然経過例に比べて IFN 治 療例では 1 - 1.5年後の観察では $\mathrm{HBe}$ 抗原・抗体采の seroconversion はあきらかに高率であり，特に活動性 病変の強い例においてその傾向がょり著明であること 
が確認された. IFNにより誘導される抗ウイルス蛋白 の2.5 OA は，長期間の IFN 投与例ではその反応が低 下することょり，長期連続投与による dosis-dependent な奻果は期待できない，間歇投与法についてこれ らの点につきさらに検討されることが望まれる．患者 白血球による in vitroでの IFN に対する2.5 OA の反 応が IFN の効果予測の指標となりらることが報告さ れ, 肝内の HBV 增殖が著明な例ではその誘導が弱く， Ara-A 等により予めウイルス増殖を抑制しておくこ とが望ましいとする意見すのべられた，IFNにより肝 内 HLA-Class I 抗原の表出が増強され，細胞性免疫反
応による感染細胞の除去が示唆されるが，細胞反応を さらに增強させる対策を考慮する必要のあることも提 唱された. ステロイド離脱燎法, SNMCが $\mathrm{HBe}$ 抗原・ 抗体系の seroconversion 率を高めることも発表され た、今回のパネルにより，B 型慢性肝炎の種々の治療 法における有效性が，病態を反映する各種マーカーを 用いた研究から一層明確にされた。今後，これらの治 㞠により，最大限の効果を得るためには，どのよらな 治療法が工夫されねばならないか，いまや治療学の第 2 の段階に入ったといえる。 